\section{Clinical Performance of Commercial ISAC 112 Allergen Microarray Versus Noncommercial RIRAAF Platform for the Diagnosis of Plant Food and Olive Pollen Allergies}

Martínez-Aranguren $\mathrm{R}^{1}$, Martínez-Botas $\mathrm{J}^{2}$, Díaz-Perales $\mathrm{A}^{3}$, Villalba $\mathrm{M}^{4}$, de la Hoz B ${ }^{5}$, Gómez $\mathrm{F}^{6}$, Bartra $\mathrm{J}^{7}$, Blanca-López $\mathrm{N}^{8}$, Alvarado $\mathrm{MI}^{9}$, Moya $\mathrm{C}^{10}$, Feo Brito $\mathrm{F}^{11}$, Alonso $\mathrm{MD}^{12}$, GonzálezMancebo $\mathrm{E}^{13}$, Terrados $\mathrm{S}^{14}$, García $\mathrm{BE}^{15}$, Gamboa $\mathrm{P}^{16}$, Parra $\mathrm{A}^{17}$, $\mathrm{D}^{\prime}$ Amelio $\mathrm{C}^{1}$, Goikoetxea $\mathrm{MJ}^{1}$, Sanz $\mathrm{ML}^{1}$

${ }^{1}$ Clínica Universidad de Navarra, Pamplona, Spain

${ }^{2}$ Servicio de Bioquímica-Investigación, Hospital Universitario Ramón y Cajal, IRYCIS, Madrid, Spain

${ }^{3}$ Departamento de Biotecnología-Biología Vegetal, Universidad Politécnica de Madrid (UPM), Madrid, Spain

${ }^{4}$ Departamento de Bioquímica y Biología Molecular I, Facultad de C. Químicas, Universidad Complutense de Madrid, Madrid, Spain

${ }^{5}$ Servicio de Alergología, Hospital Universitario Ramon y Cajal, IRYCIS, Madrid, Spain

${ }^{6}$ Servicio de Alergología, IBIMA, Regional University Hospital of Malaga, UMA, Malaga, Spain

${ }^{7}$ Unitat d'Alèrgia Servei Pneumologia i Alèrgia Respiratoria Universitat de Barcelona, Institut d'Investigacions Biomèdiques August Pi i Sunyer (IDIBAPS), Centro de Investigaciones Biomèdicas en Red de Enfermedades Respiratorias (CIBERES), Barcelona, Spain

${ }^{8}$ Servicio de Alergología, Infanta Leonor Hospital, Madrid, Spain

${ }^{9}$ Servicio de Alergia, Hospital Virgen del Puerto, Plasencia, Cáceres, Spain

${ }^{10}$ Servicio de Alergia, Complejo Hospitalario Torrecárdenas, Almería, Spain

${ }^{11}$ Servicio de Alergia, Hospital General Universitario de Ciudad Real, Ciudad Real, Spain

${ }^{12}$ Servicio de Alergia, Hospital de Alcorcón, Alcorcón, Spain

${ }^{13}$ Servicio de Alergia, Hospital de Fuenlabrada, Madrid, Spain ${ }^{14}$ Servicio de Alergología, Hospital Universitario Ramón y Cajal, IRYCIS, Madrid, Spain

${ }^{15}$ Servicio de Alergia, Complejo Hospitalario de Navarra, Pamplona, Spain

${ }^{16}$ Servicio de Alergia, Hospital de Basurto, Bilbao, Spain

${ }^{17}$ Servicio de Alergia, Hospital de A'Coruña, A'Coruña, Spain

J Investig Allergol Clin Immunol 2016; Vol. 26(3): 185-187 doi: $10.18176 /$ jiaci.00168

Key words: Allergy. Component-resolved diagnosis. slgE. Microarray. ISAC 112

Palabras clave: Alergia. Diagnóstico basado en componentes. slgE. Microarray. ISAC 112.
The combination of molecular biology and technological advances in recent years has enabled the development of new methods for the determination of serum specific $\operatorname{IgE}$ (sIgE) [1] to different allergens using a single determination method with minimal quantities of allergen and serum [2]. However, to achieve an accurate diagnostic assessment, it is still important to apply an adequate panel of allergens [3].

The ImmunoCAP ISAC 112 microarray (Thermo Fisher Scientific) is the only commercially available allergenic protein microarray, but its current panel of allergens does not seem to have the best accuracy when it comes to diagnosing food or pollen allergies in certain regions [3]. Indeed, some authors have even suggested including other allergens $[3,4]$. As part of the Spanish National Research Network of adverse reactions to allergens and drugs (RIRAAF), our team recently developed a new allergenic protein microarray model.

The aim of this study was to compare the diagnostic performance of the commercial ISAC 112 microarray and the RIRAAF microarray for the study of allergies to certain fruit (peach, apple, kiwifruit), olive pollens, and nuts in a Mediterranean area.

We prospectively enrolled 101 patients with a consistent history of an IgE-dependent reaction to peach $(n=35)$, apple $(n=16)$, kiwi $(n=7)$, peanut $(n=18)$, hazelnut $(n=15)$, and/or walnut ( $\mathrm{n}=19)$, a positive skin prick test (ALK-Abelló, Madrid, Spain), and sIgE (ImmunoCAP) to the relevant allergen sources. We also enrolled 53 patients with olive pollen allergy (rhinoconjunctivitis and/or asthma during the olive pollen season) and 28 controls. All participants were selected from the 14 participating Spanish hospitals. The research ethics committees of the participating hospitals approved the study.

The determination of $\operatorname{sigE}$ to 112 natural (n) or recombinant (r) allergens was performed using ImmunoCAP ISAC 112 in all individuals following the manufacturer's recommendations; $\operatorname{sIgE}$ was considered to be positive when the ISU value was $\geq 0.3$.

The RIRAAF microarray was applied by printing and duplicating the purified allergenic proteins (nPru p 2.2, nActd 1, nActd 2 [5], rPrup 3, rMald3, nJugr 3, nCora 8 [6], nArah1, nArah2, nArah9 [7], nOlee 1, Olee 7, and Olee9 [8]), which were then fixed on glass slides (concentration, $0.25 \mu \mathrm{g}$ / $\mu \mathrm{L}$ ) together with different concentrations of human IgE used to build a control curve. Sera pertaining to both study and control individuals were hybridized after overnight incubation at $4^{\circ} \mathrm{C}$. A murine anti-IgE antibody marked with Alexa-456 was used as a secondary antibody. The slides were scanned by ScanArray Express (PerkinElmer). The study results were expressed as a signal noise ratio (SNR) fluorescence intensity for each allergen. The SNR was considered to be positive when the value was 3 or greater (mean+2SD of controls).

Sensitivity, specificity, positive and negative predictive values, and correct classification of each patient's parameters were determined for both the ISAC and RIRAAF microarrays in order to evaluate their ability to discriminate between 
Table. Diagnostic Capacity of Microarray Platforms ISAC 112 and RIRAAF Showing Results for Individual Allergens and Allergens From Same Source

\begin{tabular}{|c|c|c|c|c|c|c|c|c|}
\hline Allergen & Platform & Sens $(\%)$ & Spec $(\%)$ & PPV (\%) & NPV (\%) & Cor Class & AUC & $P$ Value $^{\mathrm{a}}$ \\
\hline Act d 1 & $\begin{array}{l}\text { ISAC } \\
\text { RIRAAF }\end{array}$ & $\begin{array}{l}57.1 \\
14.3\end{array}$ & $\begin{array}{l}96.4 \\
92.8\end{array}$ & $\begin{array}{l}80.0 \\
17.7\end{array}$ & $\begin{array}{l}90.0 \\
68.3\end{array}$ & $\begin{array}{l}88.6 \\
77.1\end{array}$ & $\begin{array}{l}0.768 \\
0.535\end{array}$ & $.028^{\mathrm{b}}$ \\
\hline Act d 2 & $\begin{array}{l}\text { ISAC } \\
\text { RIRAAF }\end{array}$ & $\begin{array}{l}14.3 \\
28.6\end{array}$ & $\begin{array}{l}100.0 \\
85.7\end{array}$ & $\begin{array}{l}100.0 \\
33.3\end{array}$ & $\begin{array}{l}82.5 \\
82.7\end{array}$ & $\begin{array}{l}82.8 \\
74.2\end{array}$ & $\begin{array}{l}0.571 \\
0.571\end{array}$ & .999 \\
\hline Act d 5 & ISAC & 14.3 & 100.0 & 100.0 & 82.4 & 82.3 & 0.508 & \\
\hline Act d 8 & ISAC & 0.0 & 100.0 & & 80.0 & 80.0 & 0.500 & \\
\hline Kiwi allergens & $\begin{array}{l}\text { ISAC } \\
\text { RIRAAF }\end{array}$ & $\begin{array}{l}71.4 \\
28.6\end{array}$ & $\begin{array}{l}96.4 \\
78.6\end{array}$ & $\begin{array}{l}83.3 \\
25.0\end{array}$ & $\begin{array}{l}93.1 \\
81.5\end{array}$ & $\begin{array}{l}91.4 \\
68.6\end{array}$ & $\begin{array}{l}0.839 \\
0.536\end{array}$ & $.006^{\mathrm{b}}$ \\
\hline Ara h 1 & $\begin{array}{l}\text { ISAC } \\
\text { RIRAAF }\end{array}$ & $\begin{array}{c}0.0 \\
16.6\end{array}$ & $\begin{array}{c}100.0 \\
82.1\end{array}$ & 37.5 & $\begin{array}{l}60.8 \\
60.5\end{array}$ & $\begin{array}{l}60.8 \\
56.5\end{array}$ & $\begin{array}{l}0.520 \\
0.494\end{array}$ & .613 \\
\hline Ara h 2 & $\begin{array}{l}\text { ISAC } \\
\text { RIRAAF }\end{array}$ & $\begin{array}{l}0.0 \\
0.0\end{array}$ & $\begin{array}{c}100.0 \\
96.4\end{array}$ & 0.0 & $\begin{array}{l}60.8 \\
60.0\end{array}$ & $\begin{array}{l}60.8 \\
58.7\end{array}$ & $\begin{array}{l}0.520 \\
0.482\end{array}$ & .167 \\
\hline Ara h 3 & ISAC & 0.0 & 100.0 & & 60.9 & 60.9 & 0.500 & \\
\hline Ara h 6 & ISAC & 11.1 & 100.0 & 100.0 & 63.6 & 63.8 & 0.500 & \\
\hline Ara h8 & ISAC & 0.0 & 100.0 & & 60.9 & 60.9 & 0.500 & \\
\hline Ara h 9 & $\begin{array}{l}\text { ISAC } \\
\text { RIRAAF }\end{array}$ & $\begin{array}{l}61.1 \\
61.1\end{array}$ & $\begin{array}{l}100.0 \\
92.8\end{array}$ & $\begin{array}{l}100.0 \\
84.6\end{array}$ & $\begin{array}{l}80.0 \\
78.8\end{array}$ & $\begin{array}{l}84.8 \\
80.4\end{array}$ & $\begin{array}{l}0.805 \\
0.770\end{array}$ & .630 \\
\hline Peanut allergens & $\begin{array}{l}\text { ISAC } \\
\text { RIRAAF }\end{array}$ & $\begin{array}{l}61.1 \\
66.6\end{array}$ & $\begin{array}{c}100.0 \\
75.0\end{array}$ & $\begin{array}{c}100.0 \\
63.1\end{array}$ & $\begin{array}{l}80.0 \\
77.7\end{array}$ & $\begin{array}{l}84.8 \\
71.7\end{array}$ & $\begin{array}{l}0.805 \\
0.708\end{array}$ & .259 \\
\hline Cor a 1 & ISAC & 0.0 & 100.0 & & 65.1 & 65.1 & 0.500 & \\
\hline Cor a 8 & $\begin{array}{l}\text { ISAC } \\
\text { RIRAAF }\end{array}$ & $\begin{array}{l}66.6 \\
33.3\end{array}$ & $\begin{array}{l}96.4 \\
96.4\end{array}$ & $\begin{array}{l}90.9 \\
83.3\end{array}$ & $\begin{array}{l}84.4 \\
73.0\end{array}$ & $\begin{array}{l}86.0 \\
74.4\end{array}$ & $\begin{array}{l}0.815 \\
0.649\end{array}$ & $.046^{\mathrm{b}}$ \\
\hline Cor a 9 & ISAC & 6.7 & 100.0 & 100.0 & 66.7 & 67.4 & 0.500 & \\
\hline Hazelnut allergens & $\begin{array}{l}\text { ISAC } \\
\text { RIRAAF }\end{array}$ & $\begin{array}{l}73.3 \\
33.3\end{array}$ & $\begin{array}{l}96.4 \\
96.4\end{array}$ & $\begin{array}{l}91.7 \\
83.3\end{array}$ & $\begin{array}{l}87.1 \\
73.0\end{array}$ & $\begin{array}{l}88.4 \\
74.4\end{array}$ & $\begin{array}{l}0.849 \\
0.649\end{array}$ & $.004^{\mathrm{b}}$ \\
\hline Jug r 1 & ISAC & 5.3 & 100.0 & 100.0 & 60.9 & 61.7 & 0.500 & \\
\hline Jug r 2 & ISAC & 5.3 & 96.4 & 50.0 & 60.0 & 59.6 & 0.508 & \\
\hline Jug r 3 & $\begin{array}{l}\text { ISAC } \\
\text { RIRAAF }\end{array}$ & $\begin{array}{l}73.7 \\
26.3\end{array}$ & $\begin{array}{c}92.8 \\
100.0\end{array}$ & $\begin{array}{c}87.5 \\
100.0\end{array}$ & $\begin{array}{l}83.9 \\
66.7\end{array}$ & $\begin{array}{l}85.1 \\
70.2\end{array}$ & $\begin{array}{l}0.833 \\
0.631\end{array}$ & $.007^{\mathrm{b}}$ \\
\hline Walnut allergens & $\begin{array}{l}\text { ISAC } \\
\text { RIRAAF }\end{array}$ & $\begin{array}{l}84.2 \\
26.3\end{array}$ & $\begin{array}{c}89.3 \\
100.0\end{array}$ & $\begin{array}{c}84.2 \\
100.0\end{array}$ & $\begin{array}{l}89.3 \\
66.7\end{array}$ & $\begin{array}{l}87.2 \\
70.2\end{array}$ & $\begin{array}{l}0.867 \\
0.631\end{array}$ & $<.001^{\mathrm{b}}$ \\
\hline Pru p 1 & ISAC & 8.6 & 100.0 & 100.0 & 46.7 & 49.2 & 0.500 & \\
\hline Pru p 2 & RIRAAF & 5.7 & 92.9 & 50.0 & 44.1 & 44.4 & 0.507 & \\
\hline Pru p 3 & $\begin{array}{l}\text { ISAC } \\
\text { RIRAAF }\end{array}$ & $\begin{array}{l}85.1 \\
28.6\end{array}$ & $\begin{array}{l}96.4 \\
96.4\end{array}$ & $\begin{array}{l}96.7 \\
90.9\end{array}$ & $\begin{array}{l}84.4 \\
51.9\end{array}$ & $\begin{array}{l}90.5 \\
58.7\end{array}$ & $\begin{array}{l}0.911 \\
0.625\end{array}$ & $<.001^{\mathrm{b}}$ \\
\hline Peach allergens & $\begin{array}{l}\text { ISAC } \\
\text { RIRAAF }\end{array}$ & $\begin{array}{l}88.6 \\
31.4\end{array}$ & $\begin{array}{l}96.4 \\
89.3\end{array}$ & $\begin{array}{l}96.8 \\
78.6\end{array}$ & $\begin{array}{l}87.1 \\
51.0\end{array}$ & $\begin{array}{l}92.0 \\
57.1\end{array}$ & $\begin{array}{l}0.925 \\
0.603\end{array}$ & $<.001^{\mathrm{b}}$ \\
\hline Mal d 1 & ISAC & 18.8 & 100.0 & 100.0 & 68.3 & 70.4 & 0.594 & \\
\hline Mal d 3 & RIRAAF & 37.5 & 92.8 & 75.0 & 72.2 & 72.7 & 0.652 & \\
\hline Apple allergens & $\begin{array}{l}\text { ISAC } \\
\text { RIRAAF }\end{array}$ & $\begin{array}{l}18.8 \\
37.5\end{array}$ & $\begin{array}{c}100.0 \\
92.8\end{array}$ & $\begin{array}{c}100.0 \\
75.0\end{array}$ & $\begin{array}{l}68.3 \\
72.2\end{array}$ & $\begin{array}{l}70.4 \\
72.7\end{array}$ & $\begin{array}{l}0.594 \\
0.652\end{array}$ & .497 \\
\hline Ole e 1 & $\begin{array}{l}\text { ISAC } \\
\text { RIRAAF }\end{array}$ & $\begin{array}{l}81.1 \\
64.1\end{array}$ & $\begin{array}{l}82.1 \\
78.6\end{array}$ & $\begin{array}{l}89.6 \\
85.0\end{array}$ & $\begin{array}{l}62.7 \\
53.7\end{array}$ & $\begin{array}{l}81.5 \\
69.1\end{array}$ & $\begin{array}{l}0.816 \\
0.714\end{array}$ & .067 \\
\hline Ole e 7 & $\begin{array}{l}\text { ISAC } \\
\text { RIRAAF }\end{array}$ & $\begin{array}{c}15.1 \\
0.0\end{array}$ & $\begin{array}{l}100.0 \\
100.0\end{array}$ & 100.0 & $\begin{array}{l}38.3 \\
34.6\end{array}$ & $\begin{array}{l}44.4 \\
34.6\end{array}$ & $\begin{array}{l}0.575 \\
0.509\end{array}$ & $.010^{\mathrm{b}}$ \\
\hline Ole e 9 & $\begin{array}{l}\text { ISAC } \\
\text { RIRAAF }\end{array}$ & $\begin{array}{c}7.5 \\
11.3\end{array}$ & $\begin{array}{c}100.0 \\
92.8\end{array}$ & $\begin{array}{c}100.0 \\
75.0\end{array}$ & $\begin{array}{l}36.3 \\
35.6\end{array}$ & $\begin{array}{l}39.5 \\
39.5\end{array}$ & $\begin{array}{l}0.538 \\
0.521\end{array}$ & .665 \\
\hline Olive allergens & $\begin{array}{l}\text { ISAC } \\
\text { RIRAAF }\end{array}$ & $\begin{array}{l}83.0 \\
67.9\end{array}$ & $\begin{array}{l}82.1 \\
75.0\end{array}$ & $\begin{array}{l}89.8 \\
83.7\end{array}$ & $\begin{array}{l}71.9 \\
55.2\end{array}$ & $\begin{array}{l}82.7 \\
70.4\end{array}$ & $\begin{array}{l}0.826 \\
0.715\end{array}$ & .070 \\
\hline
\end{tabular}

Abbreviations: AUC, area under receiver operating characteristic curve; Corr class, correctly classified patients; NPV, negative predictive values; PPV, positive predictive values; Sens, sensitivity; Spec, specificity.

${ }^{a}$ Comparative significance between AUC values for ISAC and RIRAAF microarrays.

bignificant values $(P<.05)$. 
symptomatic patients and controls. The resulting areas under the receiver operating characteristic curve (AUC) for the allergens studied were assessed both individually and globally for the same allergenic source, and AUC values were compared between platforms (Table).

Compared with the RIRAAF microarray, the ISAC platform showed a greater ability to detect sIgE to peach, kiwifruit, hazelnut, and walnut. In fact, better sensitivity values were observed for the allergens Act d 1, Cor a 8, Jug r 3, and Prup 3 with the ISAC microarray.

The ISAC microarray also performed better at detecting sensitization to olive pollen, probably in relation to the higher sensitivity observed for Ole 1 in this platform, although the differences with the RIRAAF microarray were not statistically significant.

Both microarrays showed similar diagnostic ability for the detection of apple allergy. However, the RIRAAF microarray identified a greater number of cases due to the presence of Mald3, a lipid transfer protein (LTP) and the major apple allergen in our region. Mal d 1 is the only apple component in ISAC and is a minor allergen in our country [9].

Finally, peanut allergy was diagnosed similarly by both platforms, although the ISAC microarray detected SIgE to 3 more allergens than the RIRAAF microarray (Arah3, Arah 6, and Arah 8), suggesting their low relevance in our population.

We have described a new diagnostic tool that includes the major allergens of the studied foods [10] and of olive pollen in the Mediterranean basin. Although the RIRAAF microarray showed a greater ability to diagnose apple allergy, its sensitivity for the rest of the allergies studied was lower than that of ISAC. Despite the application of this LTP-rich panel, which may facilitate a better approach to patients in our region, the sensitivity of the RIRAAF microarray was lower than that of ISAC for most allergens. A similar sensitivity was found only for Arah9.

Different assays in previous studies by our team have shown good accuracy for most of the allergens on the RIRAAF platform [5-8]. However, its sensitivity might have been affected by suboptimal adherence of the allergens to the platform, possibly due to the formation of allergen-buffer complexes or to the lack of an individualized concentration for each allergen.

Despite the application of a well-chosen panel of allergens that allows for a better assessment of molecular sensitization according to the geographical origin of patients, we consider that multiplex platforms should be technically optimized in order to ensure better diagnostic performance. Moreover, further studies are needed to evaluate the usefulness of the commercial ISAC microarray for the diagnosis of other allergies.

\section{Funding}

This research was financially supported by grants PI 11/01634 and RD12/0013/00010 from the Spanish Research Network on Adverse Reactions to Allergens and Drugs (RIRAAF; Red de Investigación de Reacciones Adversas a Alérgenos y Fármacos) within the Instituto de Salud Carlos III.

\section{Conflicts of Interest}

The authors declare that they have no conflicts of interest.

\section{References}

1. Sanz ML, Blazquez AB, Garcia BE. Microarray of allergenic component-based diagnosis in food allergy. Curr Opin Allergy Clin Immunol. 2011 Jun;11(3):204-9.

2. Fiocchi A, Nowak-Wegrzyn A. The fascinating world of molecular diagnosis in the management of food allergy: nondum matura est. Curr Opin Allergy Clin Immunol. 2011 Jun;11(3):200-3.

3. Salcedo G, Diaz-Perales A. Component-resolved diagnosis of allergy: more is better? Clin Exp Allergy. 2010 Jun;40(6):8368.

4. Pomponi D, Bernardi ML, Liso M, Palazzo P, Tuppo L, Rafaiani C, Santoro M, Labrada A, Ciardiello MA, Mari A, Scala E Allergen micro-bead array for lgE detection: a feasibility study using allergenic molecules tested on a flexible multiplex flow cytometric immunoassay. PLoS One. 2012;7(4):e35697.

5. Palacin A, Tordesillas L, Gamboa P, Sanchez-Monge R, CuestaHerranz J, Sanz ML, Barber D, Salcedo G, Díaz-Perales A. Characterization of peach thaumatin-like proteins and their identification as major peach allergens. Clin Exp Allergy. 2010 SEP;40(9):1422-30.

6. Palacin A, Gomez-Casado C, Rivas LA, Aguirre J, Tordesillas L, Bartra J, Blanco C, Carrillo T, Cuesta-Herranz J, de Frutos C, Alvarez-Eire GG, Fernández FJ,Gamboa P, Muñoz R, SánchezMonge R, Sirvent S, Torres MJ, Varela-Losada S, Rodríguez R, Parro V, Blanca M, Salcedo G, Díaz-Perales A. Graph based study of allergen cross-reactivity of plant lipid transfer proteins (LTPS) using microarray in a multicenter study. PLOS One. 2012;7(12):e50799.

7. Javaloyes G, Goikoetxea MJ, Garcia Nunez I, Sanz ML, Blanca M, Scheurer S, Vieths S, Ferrer M. Performance of different in vitro techniques in the molecular diagnosis of peanut allergy. J Investig Allergol Clin Immunol. 2012;22(7):508-13.

8. Villalba M, Rodríguez R, Batanero $E$. The spectrum of olive pollen allergens. From structures to diagnosis and treatment. Methods. 2014 3/1;66(1):44-54

9. Gomez F, Aranda A, Campo P, Diaz-Perales A, Blanca-Lopez N, Perkins J, Garrido M, Blanca M, Mayorga C, Torres MJ. High prevalence of lipid transfer protein sensitization in apple allergic patients with systemic symptoms. PLoS One. 2014 Sep 11;9(9):e107304.

10. Ballmer-Weber BK, Hoffmann-Sommergruber K. Molecular diagnosis of fruit and vegetable allergy. Curr Opin Allergy Clin Immunol. 2011 Jun;11(3):229-35.

- Manuscript received September 7, 2015; accepted for publication, November 23, 2015.

Ruben M Martínez-Aranguren

Department of Allergy

Clínica Universidad de Navarra

Pío XII 36

31008 Pamplona, Spain

E-mail: rmmartinez@unav.es 


\section{Does the Profile of Sensitization to Grass Pollen Allergens Have Clinical Relevance?}

Palao-Ocharan $\mathrm{P}^{1}$, Domínguez-Ortega $\mathrm{J}^{1}$, Barranco $\mathrm{P}^{1,2}$, DiazAlmiron $\mathrm{M}^{3}$, Quirce $\mathrm{S}^{1,2}$

${ }^{1}$ Department of Allergy, Hospital La Paz Institute for Health Research (IdIPAZ), Madrid, Spain

${ }^{2}$ CIBER de Enfermedades Respiratorias, CIBERES, Madrid, Spain

${ }^{3}$ Department of Biostatistics, Hospital Universitario La Paz, Madrid, Spain

J Investig Allergol Clin Immunol 2016; Vol. 26(3): 188-189 doi: 10.18176/jiaci.0043

Key words: Recombinant allergens. Molecular diagnosis. Grass pollen allergy. Allergic rhinoconjunctivitis and asthma.

Palabras clave: Alérgenos recombinantes. Diagnóstico molecular. Alergia a polen de gramíneas. Rinoconjuntivitis y asma alérgicas.

Grass pollen is the most common cause of seasonal respiratory allergy worldwide, and affects $8 \%$ to $25 \%$ of the general population [1-2]. In recent years, component-resolved diagnosis (CRD) using measurements of specific IgE to individual allergens (either natural or recombinant) is being increasingly used. CRD has improved the diagnostic workup of allergy to pollen, allowing more accurate evaluation of sensitization profiles and differentiation between true cosensitization and cross-reactivity to pollen allergens [3]. Several allergenic components are available for CRD of grass pollen allergy (Phleum pratense). The most widely used components are $\mathrm{rPhlp} 1$ and $\mathrm{rPhl} p 5$, as markers of genuine sensitization, and rPhlp 12 (profilin) and rPhl 7 (polcalcin), as panallergens considered responsible for cross-reactivity with other pollens [4-5]. However, the clinical implications of sensitization patterns to different pollen allergens in sensitized patients are unknown.

In the present study we evaluated the profile of sensitization to recombinant grass pollen allergens and explored its potential association with different clinical features among patients allergic to grass pollen living in the northern area of Madrid, Spain. The study was approved by the local ethics committee (HULP PI-1682).

In this retrospective study, we included 248 patients diagnosed with grass pollen allergy in the previous year; they had a positive skin prick test to mixed grass pollen extract (ALK-Abelló, Madrid, Spain) and positive specific $\operatorname{IgE}$ measurement $(>0.35 \mathrm{kU} / \mathrm{L})$ to at least 1 of the following recombinant allergens: $\mathrm{rPhl} \mathrm{p} 1, \mathrm{rPhl} \mathrm{p} 5, \mathrm{rPhl}$, and $\mathrm{rPhl} \mathrm{p} 12$ (InmunoCAP, Thermo Fisher Scientific). The patients (132 men) ranged in age from 3 to 68 years old (mean age, 21.3) and $85.9 \%$ were white (Hispanic, $10.1 \%$ ).

A family history of atopy was found in $46.4 \%$ of patients. Rhinitis was the most frequent disorder $(97.6 \%)$ and was commonly associated with conjunctivitis (96\%). Most patients $(84.7 \%)$ had persistent rhinitis, and $186(75 \%)$ had asthma, which was persistent in $79 \%$ of cases and controlled in $64.5 \%$. Demographic data are summarized in the Table. The mean duration of rhinitis and asthma was 5.83 and 5.81 years, respectively. Median forced expiratory volume in the first second ( $\%$ predicted) in the pollen season was $100 \%$ (range, 57\%-144\%), and median total serum IgE was $281 \mathrm{kU} / \mathrm{L}$ (range, $27-1865 \mathrm{kU} / \mathrm{L}$ ). Of the 248 patients studied, 244 (98\%) were sensitized to $\mathrm{rPhl} p 1$ (median, $26.1 \mathrm{kU} / \mathrm{L}$; range, 0.39$101 \mathrm{kU} / \mathrm{L}), 141$ (56.8\%) to $\mathrm{rPhl} \mathrm{p} 5$ (median, $16.5 \mathrm{kU} / \mathrm{L}$; range, 0.38-101 kU/L), 35 (14.1\%) to rPhlp 12 (median, 7.36; range, 0.36-69 kU/L), and 11 (4.4\%) to rPhlp 7 (median, 4.73; range, 0.51-100 kU/L).

Ninety-three percent of the study population were sensitized to pollens other than grasses (average of 3 pollen sources) and 53.3\% were sensitized to animal dander (37.8\%, dog; $15.5 \%$, cat; $7.7 \%$, horse; and $1.6 \%$, hamster). Sensitization to house dust mites and molds was found in $26.2 \%$ and $17.7 \%$ of patients, respectively.

No association was found between different sensitization patterns to grass pollen allergens and clinical features of asthma or rhinitis (severity, control, duration, etc.). The only significant association observed was between the progression of rhinitis to asthma and longer duration of rhinitis $(P=.012)$. A numerical trend approaching statistical significance was observed between being sensitized to $\mathrm{rPhl} \mathrm{p} 1$ and the presence of asthma $(P=.054)$. A significant positive correlation was observed between age and duration of rhinitis/asthma (Pearson correlation coefficients of 0.561 and 0.568 , respectively), and a negative relationship was observed between sensitization to $\mathrm{rPhl} p 1$ and duration of both disorders (-1.118 and -1.181 respectively). Surprisingly, no association was found between severity of rhinitis and asthma, although the development of asthma was associated with a longer duration of rhinitis. Moreover, there was little difference between the duration of both diseases, possibly in relation to the characteristics of the study population (all referred to a tertiary hospital).

Between $50 \%$ and $80 \%$ of patients referred to an allergist in Spain are polysensitized [6]. Identification of the relevant allergen can be difficult in patients sensitized to various pollens in areas with overlapping pollen seasons. In one Spanish study, of $99.4 \%$ of patients allergic to grass pollen who were polysensitized to unrelated pollens according to CRD with $\mathrm{rPhl}$ p 1, rPhl p 5, rPhl p 7, and rPhl p 12, only 36\% were considered to be truly polysensitized after allergenic crossreactivity had been ruled out [7]. In our study, considering that sensitization to profilin ( $\mathrm{rPhl} \mathrm{p} \mathrm{12)} \mathrm{was} \mathrm{present} \mathrm{in} 14.1 \%$ of patients and sensitization to polcalcin ( $\mathrm{rPhl} \mathrm{p} 7$ ) in $4.4 \%$, CRD might be helpful for prescribing immunotherapy in these patients[8], but, overall, it alone cannot justify the high rate of polysensitized patients detected. It is noteworthy that $86.8 \%$ of patients had persistent rhinitis, which could be explained by the high frequency of polysensitization in this population sample. It is also worth remarking that in children, the prevalence of sensitization to $\mathrm{rPhl}$ p 5 was lower than in adults, as previously described by Scaparrotta et al [9] in a study of 207 children under 10 years of age.

Savi et al [10] found a significant association between severe persistent rhinitis and the presence of asthma and, in keeping with our results, no correlation was observed between 
severity of rhinitis and levels of specific $\operatorname{IgE}$ to $\mathrm{rPhl} p 1$, rPhlp 5, rPhlp 7, or rPhlp 12. Only low levels of specific IgE to rPhlp 5 were associated with the absence of asthma in patients allergic to grass pollen. By contrast, in our study we found no evidence to suggest that asthma is associated with a particular sensitization profile. Furthermore, although a numerical trend showed that being sensitized to rPhl p 1 may be associated with the development of asthma, this observation could also be explained by the fact that $\mathrm{rPhl} p 1 \mathrm{IgE}$ levels are also significantly associated with duration of allergic respiratory disease and, therefore, with longer duration of exposure to grass pollen.

In conclusion, we did not identify any relationship between the molecular sensitization profile and clinical features of respiratory allergy in this population. Only higher IgE levels to $\mathrm{rPhlp} 1$ seem to be associated with longer disease duration.

Funding

The authors declare that no funding was received for the present study.

Conflicts of Interest

The authors declare that they have no conflicts of interest.

\section{References}

1. Bauchau $V$, Durham SR. Prevalence and rate of diagnosis of allergic rhinitis in Europe. Eur Respir J. 2004;24:758-64.

2. Dahl R, Andersen PS, Chivato T, Valovirta E, de Monchy J. National prevalence of respiratory allergic disorders. Respir Med. 2004;98:398-403.

3. Migueres M, Dávila I, Frati F, Azpeitia A, Jeanpetit $Y$, Lheritier Barrand M, Incorvaia C, Ciprandi G. Types of sensitiation to aeroallergens: definitions, diagnosis and treatment of allergic respiratory disease. Clin Transl Allergy2014; 4:16

4. Canis M, Gröger M, Becker S, Klemens C, Kramer MF. Recombinant marker allergens in diagnosis of patients with allergic rhinoconjunctivitis to tree and grass pollens. Am J Rhinol Allergy. 2011;25:36-9.

5. Sastre J. Molecular diagnosis and immunotherapy. Curr Opin Allergy Clin Immunol. 2013;13:646-50

6. Pereira C, Valero A, Loureiro C, Dávila I, Martínez-Cócera C, Murio C, Rico P, Palomino R. Iberian study of aeroallergens sensitization in allergic rhinitis. Eur Ann Allergy Clin Immunol. 2006;38:186-94.

7. Casquete-Román E, Rosado-Gil T, Postigo I, Pérez-Vicente R, Fernández M, Torres HE, Martínez-Quesada J. Contribution of molecular diagnosis of allergy into the management of pediatric patients with allergy to pollen. J Investig Allergol Clin Immunol. 2009; 19:439-45.

8. Moreno C, Justicia JL, Quiralte J, Moreno-Ancillo A, IglesiasCadarso A, Torrecillas M, Labarta N, García MA, Dávila I. Olive, grass or both? Molecular diagnosis for the allergen immunotherapy selection in polysensitized pollinic patients. Allergy. 2014;69:1357-63.

9. Scaparrotta $A$, Verini $M$, Consilvio N Pietro, Cingolani $A$, Rapino D, Attanasi M, Cerasa M, Di Pillo S, Chiarelli F.
Sensitization to timothy grass pollen allergenic molecules in children. Multidiscip Respir Med. 2013;8:17.

10. Savi E, Peveri S, Incorvaia C, Dell'Albani I, Marcucci F, Di Cara G, Frati F. Association between a low lgE response to Phl p 5 and absence of asthma in patients with grass pollen allergy. Clin Mol Allergy. 2013;11:3.

Manuscript received October 1, 2015; accepted for publication, November 23, 2015.

Paola Palao-Ocharan

Paseo de la Castellana 261

28046 Madrid, Spain

E-mail: paolapalao@gmail.com 


\section{Non-asthmatic Eosinophilic Bronchitis and Idiopathic Eosinophilic Esophagitis}

Gómez Torrijos $\mathrm{E}^{1}$, Mur Gimeno $\mathrm{P}^{2}$, Martín Iglesias $\mathrm{A}^{2}$, García Rodriguez $\mathrm{R}^{1}$, Galindo Bonilla $\mathrm{P}^{1}$, El Kaddioui $\mathrm{S}^{3}$, Mendez Díaz $\mathrm{YC}^{1}$, Quirce Gancedo $\mathrm{S}^{4}$

${ }^{\prime}$ Allergy Section, Hospital General de Ciudad Real, Ciudad Real, Spain

${ }^{2}$ Allergy Unit, Hospital Santa Bárbara, Puertollano, Ciudad Real, Spain

${ }^{3}$ General Practitioner, Puertollano, Ciudad Real, Spain

${ }^{4}$ Department of Allergy. Hospital La Paz Institute for Health Research (IdiPAZ), Madrid

J Investig Allergol Clin Immunol 2016; Vol. 26(3): 190-191 doi: 10.18176/jiaci.0045

Key words: Eosinophilic esophagitis. Eosinophilic bronchitis. Dysphagia. Respiratory symptoms. Eosinophils.

Palabras clave: Esofagitis eosinofílica. Bronquitis eosinofílica. Disfagia. Síntomas respiratorios. Eosinófilos.

Non-asthmatic eosinophilic bronchitis (NAEB), which was first described by Gibson et al [1] in 1989, is now considered a relatively common cause of chronic cough. It is characterized by persistent dry cough, with little or abundant sputum, and bronchial eosinophilic inflammation (similar to that seen in asthma) with sputum eosinophilia equal to or greater than $3 \%$. Unlike asthma, bronchial hyperresponsiveness is not observed in pulmonary function tests $[1,2]$.

Eosinophilic esophagitis (EoE) in adults was described as a separate clinicopathological entity by Attwood et al [3] in 1993. It has been defined as an antigen-mediated chronic esophageal disease characterized by symptoms of esophageal dysfunction and predominant eosinophilic inflammation, with at least 15 eosinophils per high-power field (eos/hpf) [4].

We report an unusual case of NAEB and EoE coexisting in the same patient characterized by eosinophilic inflammation and involvement of 2 organs (bronchi and esophagus). A 47-year-old man working as a clerk in an optician's where glasses were sold but not repaired was referred to our allergy department for consultation. He had a history of factitious urticaria and good response to oral antihistamines and reported gastrointestinal symptoms of 2 years' duration, consisting of dyspepsia and dysphagia for solid foods, without clear signs of choking, and chest pain unrelated to food intake. He also had respiratory symptoms, including sneezing, nasal congestion, and itchy eyes, nose, and throat, accompanied by dry cough and slight dyspnea without audible wheezing. The cardiopulmonary and abdominal examination was normal. A routine analytical work-up detected blood eosinophilia of $1560 \mathrm{eos} / \mathrm{mcL}$, which 6 months later decreased to 492 eos/mcL. Serology for hepatitis B and C virus, human immunodeficiency virus, and fecal parasites were within normal ranges. The electrocardiogram showed a sinus rhythm of $65 \mathrm{bpm}$, and the chest $\mathrm{x}$-ray showed no significant alterations.

Upper endoscopy showed over 50 eos/hpf in the proximal and distal esophageal segment and 10 eos/hpf in the middle segment; no eosinophils were detected in the stomach or duodenum. Treatment with omeprazole $80 \mathrm{mg} / \mathrm{d}$ was prescribed for 2 months, after which a new esophagoscopy showed over 50 eos/hpf in the 3 esophageal sections.

Skin prick tests were performed with common aeroallergens consisting of pollens (grass, olive, Cupressaceae, Platanus acerifolia, Chenopodiaceae), mites, molds, and cat and dog dander. They were positive for grass $(3 \times 3 \mathrm{~mm})$, olive $(4 \times 4 \mathrm{~mm})$, Dermatophagoides pteronyssinus $(5 \times 3 \mathrm{~mm})$, and Dermatophagoides farinae $(4 \times 3 \mathrm{~mm})$. Skin prick tests with food-wheat, lentils, peanuts, eggs, milk, hake, shrimp, lipid transfer protein, and profilin-were negative.

Total IgE was $214 \mathrm{kU} / \mathrm{L}$ and specific IgE (sIgE) values, measured by ImmunoCAP, were $3.01 \mathrm{kU} / \mathrm{L}$ for Ole e 1, $3.32 \mathrm{kU} / \mathrm{L}$ for $D$ pteronyssinus, $2.04 \mathrm{kU} / \mathrm{L}$ for $D$ farinae, $1.48 \mathrm{kU} / \mathrm{L}$ for milk, $1.16 \mathrm{kU} / \mathrm{L}$ for wheat, $0.95 \mathrm{kU} / \mathrm{L}$ for peanut, and $0.62 \mathrm{kU} / \mathrm{L}$ for lentil. sIgE for shrimp, hake, and egg were all under $0.35 \mathrm{kU} / \mathrm{L}$. Baseline forced spirometry and a postbronchodilator test were normal. A methacholine challenge using the semiabbreviated Chai method [5] was negative up to $400 \mathrm{IU}$. We did not perform a bronchial hyperreactivity test with adenosine because its use is not allowed in humans. Spontaneous sputum cytology showed $80 \%$ eosinophils, $17 \%$ epithelial cells, $1 \%$ erythrocytes, and $2 \%$ neutrophils.

The patient was diagnosed with EoE and prescribed an elimination diet of grains, legumes, nuts, and milk, based on the allergy test results. After 6 weeks, the esophagoscopy was repeated and over 30 eos/hpf persisted in the 3 esophageal segments. An empirical elimination diet with 6 food groups was extended for an additional 6 weeks, after which a new esophagoscopy detected over $50 \mathrm{eos} / \mathrm{hpf}$ in the lower section and 6 eos/hpf in the upper section.

We established a diagnosis of mild allergic rhinoconjunctivitis due to mites and pollens, eosinophilic bronchitis, and idiopathic eosinophilic esophagitis. The patient's rhinoconjunctivitis did not require treatment with antihistamines, and his cough subsided after 2 months of treatment with budesonide $400 \mathrm{mcg} / 12 \mathrm{~h}$, with no recurrence in subsequent months. The patient reported only intermittent retrosternal chest pain.

We have described the presence of 2 rare clinical entities in the same patient: EoE and NAEB. The relatively recent description of both diseases [1,3] might explain why underdiagnosis is still common. Both conditions affect middleaged individuals $[2,6]$, but EoE is more common in atopic men $[2,4,6]$.

Despite our exhaustive studies, we were unable to detect the cause of either disease. A chronic cough of 2 years' duration requires ruling out the involvement of house dust mites. This condition, however, is unlikely because our patient lives in a central part of Spain with a dry, extreme climate where patients sensitized to mites usually only experience mild symptoms in spring and autumn. If mites were the causative agent, we would expect to see improvement in cough and dysphagia symptoms in summer and winter. We ruled out the involvement of grass 
and olive pollens because these allergens are present only in spring. We also considered the possibility of occupational exposure [7-9] for both NAEB and EoE, but after a thorough medical history, we found no relationship between symptoms of either disease with the patient's work or, indeed, hobbies. We were unable to determine whether the EoE in our patient was caused by food allergens or inhaled allergens, although the former route is more common $[7,10]$.

NAEB improved clinically with inhaled topical corticosteroids [2], which not only led to a very significant reduction in sputum eosinophils but also decreased the intensity and sensitivity of the cough reflex. We also observed a reduction in bronchial hyperreactivity, although this was always within the normal range [2]. EoE did not remit after an elimination diet based on the allergy test results or after a subsequent 6-food elimination diet [10].

We think that the persistent and intermittent retrosternal chest pain in our patient may be secondary to his esophageal dysfunction, since the EoE did not go into remission [6].

Our patient had significant peripheral eosinophilia (1560 eos/mcL) alternating with mild eosinophilia (492 eos/mcL) before treatment with inhaled corticosteroids and elimination diets, probably in relation to his atopic condition.

We have presented the first report of a patient with mild atopic peripheral eosinophilia who was simultaneously diagnosed with idiopathic NAEB and idiopathic EoE.

\section{Funding}

The authors declare that no funding was received for the present study.

\section{Conflicts of Interest}

The authors declare that they have no conflicts of interest.
6. Castro Jiménez A, Gómez Torrijos E, García Rodríguez R, Feo Brito F, Borja Segade J, Galindo Bonilla PA RodriguezSanchez J and Gerra Pasadas F Demographic, clinical and allergological characteristics of Eosinophilic Esophagitis in a Spanish central region. Allergol Immunopathol (Madr) 2014 Sep-Oct; 42(5):407-14.

7. Quirce S, Fernández-Nieto M, de Miguel J, Sastre J. Chronic cough due to latex-induced eosinophilic bronchitis. J Allergy Clin Immunol. $2001 \mathrm{Jul} ;$ 108(1):143.

8. Quirce S. Eosinophilic bronchitis in the workplace. Curr Opin Allergy Clin Immunol. 2004 Apr;4(2):87-91.

9. Gomez Torrijos E, García Rodriguez C, Rodriguez J, De la Roca F, Cárdenas R, Alfaya T, Pineda F, Feo Brito JF. Occupational Asthma and Eosinophilic Esophagitis in a Patient with EggBird Syndrome. J Investig Allergol Clin Immunol 2015; Vol. 25(1):445-6.

10. Rodríguez-Sánchez J, Gómez Torrijos E, López Viedma B, de la Santa Belda E, Martín Dávila F, García Rodríguez C, Feo Brito JF and Olmedo Camacho J. Efficacy of IgE-targeted vs empiric six-food elimination diets for adult eosinophilic oesophagitis J. Allergy. 2014 Jul;69(7):936-4.

Manuscript received July 29, 2015; accepted for publication, December 22, 2015.

Elisa Gómez Torrijos

Sección de Alergología Hospital General Universitario de Ciudad Real. C/ Obispo Rafael Torija s.n. 13005-Ciudad Real. Spain E-mail: egomezt.cr@gmail.com

\section{References}

1. Gibson PG, Dolovich J, Denburg EH, Ramsdale EH, Hargreave FE. Chronic cough: eosinophilic bronchitis without asthma. Lancet 1989;1:1346-8.

2. Quirce S. Bronquitis eosinofílica no asmática. Medicina respiratoria. 2009;2(1):7-14.

3. Attwood SE, Smyrk TC, Demeester TR, Jones JB. Esophageal eosinophilia with dysphagia. A distinct clinicopathologic syndrome. Dig Dis Sci 1993;38:109-116.

4. Liacouras CA, Furuta GT, Hirano I, Atkins D, Attwood SE, Bonis PA, Burks AW, Chehade M, Collins MH, Dellon ES, Dohil R, Falk GW, Gonsalves N, Gupta SK, Katzka DA, Lucendo AJ, Markowitz JE, Noel RJ, Odze RD, Putnam PE, Richter JE, Romero Y, Ruchelli E, Sampson HA, Schoepfer A, Shaheen NJ, Sicherer SH .Eosinophilic esophagitis: updated consensus recommendations for children and adults. J Allergy Clin Immunol. 2011 Jul; 128(1):3-20.

5. Chai $H$, Farr RS, Froehlich LA, Mathison DA, McLean $J A$, Rosenthal RR, Sheffer AL, Spector SL, Townley RG. Standardization of bronchial inhalation challenge procedures. J Allergy Clin Immunol. 1975;56:323-7. 


\section{Pollen Counts Influence Web Searches for Asthma and Rhinitis}

Gaspar Marques $\mathrm{J}^{1,2}$, Carreiro Martins $\mathrm{P}^{1,2,3,4}$, Belo $\mathrm{J}^{1}$, Alves $\mathrm{C}^{1}$, Paiva $\mathrm{M}^{1}$, Caeiro $\mathrm{E}^{4,5}$, Leiria-Pinto $\mathrm{P}^{1,2}$

${ }^{I}$ Serviço de Imunoalergologia, Hospital de Dona Estefânia, Centro Hospitalar de Lisboa Central, EPE, Rua Jacinta Marto, 1169-045 Lisbon, Portugal

${ }^{2}$ CEDOC, Faculdade de Ciências Médicas (FCM), Universidade Nova de Lisboa, Campo dos Mártires da Pátria, 130, 1169-056, Lisbon, Portugal

${ }^{3}$ Epidemiology and Statistics Analysis Unit, Research Centre, Centro Hospitalar de Lisboa Central, EPE, Rua Jacinta Marto, 1169-045, Lisbon, Portugal

${ }^{4}$ Portuguese Society of Allergy and Clinical Immunology, Portugal ${ }^{5}$ Instituto de Ciências Agrárias e Ambientais Mediterrânicas, Universidade de Évora, Évora, Portugal

J Investig Allergol Clin Immunol 2016; Vol. 26(3): 192-194 doi: 10.18176/jiaci.0047

Key words: Asthma. Rhinitis. Pollen grains. Search engine.

Palabras clave: Asma. Rinitis. Granos de polen. Motor de búsqueda.

Asthma and allergic rhinitis (AR) represent a major health problem, as both diseases are relatively common and cause significant symptoms that interfere with the lives of those affected $[1,2]$. In Portugal, asthma affects approximately $7 \%$ of the population [1], while AR affects up to $26 \%$ [2]. Aeroallergens are common asthma and AR triggers [3] and are usually classified as indoor, outdoor (pollens and molds), or occupational [4]. Previous studies have confirmed the association between pollen levels and asthma-related emergency department visits [5], but no data are available on other resources used by patients. Google Trends (GT) is a web-based search tool that indicates trends related to specific Google queries over a defined period of time [6]. Its utility in allergic disease monitoring has been evaluated only in terms of the relationship between total pollen counts and rhinitis and only in relation to searches in English and German [7,8]. No studies to our knowledge have analyzed GT search trends for asthma, other languages, or individual pollens. The aim of this study was to explore the correlation between pollen counts and GT searches for asthma, rhinitis, and the main pollens associated with these diseases.

We conducted an ecological study using web and pollen count data available for Lisbon (Portugal) from 2007 to 2012 (6 years). Pollen count data were collected from Lisbon's monitoring station (Mediterranean climate; Csa KöppenGeiger Climate Classification). Counts and concentrations were analyzed using the Hirst volumetric method, following a standardized protocol from the International Association of Aerobiology. The following pollens were analyzed: Betulaceae, Castanea, Chenopodiaceae, Compositae, Cupressaceae, Myrtaceae, Olea, Palmae, Parietaria, Pinaceae, Plantago,
Platanus, Poaceae, Quercus suber, Quercus, Rumex, Salix, Umbelliferae, and Urtica. GT works by analyzing how many Google searches are done for the terms entered relative to the total number of searches in the same time period and region. GT results were extracted for rhinitis and asthma search terms in the Lisbon region from 2007 to 2012. As the GT search index was only available for monthly periods, we calculated average monthly pollen counts based on the daily data available. Total pollen count trends were transformed using a similar methodology to that of GT to allow comparisons with GT indices and to present the results graphically using a scale of 0 (minimum during study period) to 1 (maximum) [6]. The pollen count index at a specific time point corresponds to the ratio between pollen counts at that point and maximum pollen counts during the study period. Subsequently, GT results for rhinitis and asthma were correlated with total pollen counts using Spearman's rank-order correlation, after confirming a monotonic relationship. Pollens with peak levels lower than 30 grains $/ \mathrm{m}^{3}$ - the clinically relevant cutoff-were excluded. Spearman's rank-order correlation coefficients were categorized as follows: $1-0.75$, strong correlation; 0.75 0.25 , moderate correlation; and $0.1-0.25$, weak correlation. A significance level of $\alpha=0.05$ was used although $P$ values of over .05 and under .10 were also considered.

From 2007 to 2012, the median total pollen count was 43.8 grains $/ \mathrm{m}^{3} / \mathrm{mo}$ (interquartile range, $19.8-200.3$ grains $/ \mathrm{m}^{3} / \mathrm{mo}$ ). The main pollens identified in the study period, expressed as a percentage of total pollens, were Urtica (18.3\%), Cupressaceae (15.1\%), Olea (12.9\%), Parietaria (10.9\%), and Quercus (10.2\%). Total pollen counts and search trends for rhinitis showed a cyclical seasonal pattern, with peaks in spring months (March-June). Asthma search trends showed a similar, though less pronounced, pattern. Total pollen counts and search trends for asthma and rhinitis during the study period are presented in the Figure. Total pollen count had a statistically significant positive correlation with the GT search index for rhinitis $(\mathrm{r}=0.366 ; P=.002$; moderate $)$ and asthma ( $\mathrm{r}=0.305 ; P=.009$; moderate). The following pollens, based on the cutoff of over 30 grains $/ \mathrm{m}^{3}$, were analyzed in GT: Cupressacea, Olea, Parietaria, Platanus, Poaceae, Quercus suber, Quercus, and Urtica. Individual pollen counts with a statistically significant correlation with the GT search index for asthma were Cupressaceae $(\mathrm{r}=0.402 ; P<.001$; moderate), Platanus (r=0.255; $\mathrm{P}=.031$; moderate), Quercus $(\mathrm{r}=0.337 ; P=.004 ;$ moderate $)$, and Urtica $(\mathrm{r}=0.432 ; P<.001$; moderate). The same individual pollens were identified for rhinitis: Cupressaceae ( $\mathrm{r}=0.461, P<.001$, moderate), Platanus ( $\mathrm{r}=0.285, P=.015$, moderate); Quercus $(\mathrm{r}=0.231, P=.051$, weak); and Urtica ( $\mathrm{r}=0.431, P<.001$, moderate).

The pollen levels and main pollen species identified in this study are comparable to findings previously reported for Lisbon and Mediterranean areas of Europe [9]. Associations between total pollen counts and web searches for rhinitis have been previously reported [7,8], although this is the first study to compare searches in a language other than English or German and in an area with a Mediterranean climate. Moreover, to the best of our knowledge, our study is the first to analyze the correlation between specific pollens and web searches for asthma and rhinitis. A weaker though still significant 


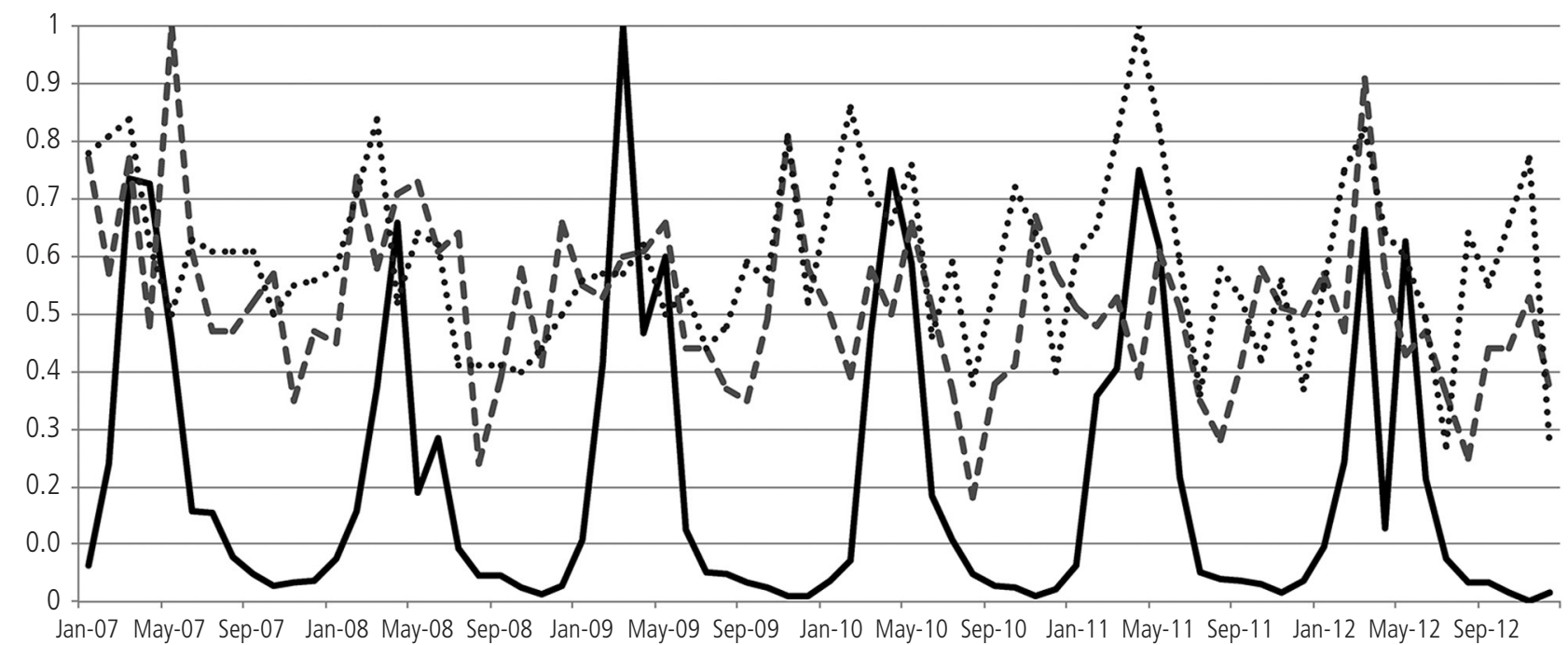

- Transformed pollen index

- Asthma (Google Trends Index)

.... Rhinitis (Google Trends Index)

Figure. Total pollen counts and Google Trends search indices for asthma and rhinitis during study period (2007-2012).

correlation was found between total pollen counts and the GT search index for asthma. One possible explanation for this weaker correlation is that the second peak period detected in winter months was probably associated with respiratory infections, an important asthma trigger [3]. The specific pollens that were significantly and positively correlated with web searches for rhinitis and asthma (Cupressaceae, Platanus, Quercus, and Urtica) are not a common cause of respiratory allergic disease in Portugal. Several explanations for this discrepancy are possible, including the fact that pollens contain different components that can stimulate an innate immune response [10] and that these pollens are more "visible", perhaps bringing patients to believe that they are responsible for their symptoms.

Our results indicate that patients with AR and asthma seek information about their diseases on the Internet, especially in pollen seasons. Little, however, is known about which online sources patients use for this purpose. As the preferential, or topranking, websites identified by search engine algorithms could be erroneous, special attention should be paid to the reliability and quality of websites providing medical information.

In conclusion, total pollen counts are significantly correlated with web searches for information on rhinitis and asthma, independently of the search language or climate area. Website monitoring is important for patients and the medical community and GT may constitute an essential tool for predicting asthma and AR outbreaks.

\section{Acknowledgments}

Portuguese Aerobiology Network and Portuguese Society of Allergy and Clinical Immunology (SPAIC).
Funding

The authors declare that no funding was received for the present study.

Conflicts of Interest

The authors declare that they have no conflicts of interest.

\section{References}

1. Sa-Sousa $A$, Morais-Almeida $M$, Azevedo $L F$, Carvalho $R$, Jacinto T, Todo-Bom A, Loureiro C, Bugalho-Almeida A, Bousquet J, Fonseca JA. Prevalence of asthma in Portugal The Portuguese National Asthma Survey. Clin Transl Allergy. 2012;2(1):15.

2. Todo-Bom A, Loureiro C, Almeida MM, Nunes C, Delgado L, Castel-Branco G, Bousquet J. Epidemiology of rhinitis in Portugal: evaluation of the intermittent and the persistent types. Allergy. 2007;62(9):1038-43.

3. Vernon MK, Wiklund I, Bell JA, Dale P, Chapman KR. What do we know about asthma triggers? a review of the literature. J Asthma. 2012;49(10):991-8.

4. Bousquet J, Khaltaev N, Cruz AA, Denburg J, Fokkens WJ, Togias A, Zuberbier T, Baena-Cagnani CE, Canonica GW, van Weel C, Agache I, Ait-Khaled N, Bachert C, Blaiss MS, Bonini S, Boulet LP, Bousquet PJ, Camargos P, Carlsen KH, Chen Y, Custovic A, Dahl R, Demoly $P$, Douagui $H$, Durham SR, van Wijk RG, Kalayci O, Kaliner MA, Kim YY, Kowalski ML, Kuna P, Le LT, Lemiere C, Li J, Lockey RF, Mavale-Manuel S, Meltzer EO, Mohammad Y, Mullol J, Naclerio R, O'Hehir RE, Ohta K, Ouedraogo S, Palkonen S, Papadopoulos N, Passalacqua G, 
Pawankar R, Popov TA, Rabe KF, Rosado-Pinto J, Scadding GK, Simons FE, Toskala E, Valovirta E, van Cauwenberge P, Wang DY, Wickman M, Yawn BP, Yorgancioglu A, Yusuf OM, Zar H, Annesi-Maesano I, Bateman ED, Ben Kheder A, Boakye DA, Bouchard J, Burney P, Busse WW, Chan-Yeung M, Chavannes $\mathrm{NH}$, Chuchalin A, Dolen WK, Emuzyte R, Grouse L, Humbert M, Jackson C, Johnston SL, Keith PK, Kemp JP, Klossek JM, Larenas-Linnemann D, Lipworth B, Malo JL, Marshall GD, Naspitz C, Nekam K, Niggemann B, Nizankowska-Mogilnicka E, Okamoto Y, Orru MP, Potter P, Price D, Stoloff SW, Vandenplas O, Viegi G, Williams D, World Health O, Galen, AllerGen. Allergic Rhinitis and its Impact on Asthma (ARIA) 2008 update (in collaboration with the World Health Organization, GA(2)LEN and AllerGen). Allergy. 2008;63 Suppl 86:8-160.

5. Jariwala S, Toh J, Shum M, de Vos G, Zou K, Sindher S, Patel P, Geevarghese A, Tavdy A, Rosenstreich D. The association between asthma-related emergency department visits and pollen and mold spore concentrations in the Bronx, 20012008. J Asthma. 2014;51(1):79-83.

6. Google Trends Lab [5 January 2015]. Available from: https:// trends.google.com/trends/.

7. Kang MG, Song WJ, Choi S, Kim H, Ha H, Kim SH, Cho SH, Min $\mathrm{KU}$, Yoon S, Chang YS. Google unveils a glimpse of allergic rhinitis in the real world. Allergy. 2015;70(1):124-8.

8. Konig V, Mosges R. A model for the determination of pollen count using google search queries for patients suffering from allergic rhinitis. J Allergy (Cairo). 2014;2014:381983.

9. Caeiro E, Brandão R, Salomé C, Lopes L, Morais-Almeida M, Oliveira JF, Todo-Bom A, Leitão T, Nunes C. The Portuguese Aerobiology Network: Airborne pollen results (2002-2006). Rev Port Imunoalergologia. 2007;15(3):235-50.

10. Hosoki K, Boldogh I, Sur S. Innate responses to pollen allergens. Curr Opin Allergy Clin Immunol. 2015;15(1):79-88.

I Manuscript received September 3, 2015; accepted for publication, December 22, 2015.

\author{
João Gaspar Marques \\ Serviço de Imunoalergologia \\ Hospital de Dona Estefânia \\ Centro Hospitalar de Lisboa Central \\ EPE, Rua Jacinta Marto \\ 1169-045 Lisbon, Portugal \\ E-mail: gasparmarques@yahoo.com.br
}

\section{Electroconvulsive Therapy in Patients with C1 Inhibitor Deficiency: A Major or Minor Procedure?}

Callero A, Gonzalez-Colino C, Perez-Rodriguez E, MartinezTadeo JA, Barrios-Recio J, Garcia-Robaina JC Allergy Department, Hospital Universitario Nuestra Señora de Candelaria, Tenerife, Spain

J Investig Allergol Clin Immunol 2016; Vol. 26(3): 194-195 doi: $10.18176 /$ jiaci.0050

Key words: Hereditary angioedema. C1 inhibitor. Purified C1 inhibitor. Depression. Electroconvulsive therapy.

Palabras clave: Angioedema hereditario. C1 inhibidor. C1 inhibidor purificado. Depresión. Terapia electroconvulsiva.

Electroconvulsive therapy (ECT) has been used for the treatment of psychiatric conditions since the 1940s. Although considered controversial in the past, ECT has proven acceptable for specific conditions [1]. Nowadays, it is indicated for severe depression, schizophrenia, bipolar disorder, and schizoaffective disorder. The procedure involves application of a small electric current to produce a generalized cerebral seizure under general anesthesia and is repeated at least 6 to 8 times before evaluating the clinical response [2].

Hereditary angioedema (HAE) is a genetic defect caused by a lack of the protein $\mathrm{C} 1$ esterase inhibitor (C1-INH). Consequently, the body does not produce sufficient quantities of the protein (type $1 \mathrm{HAE}$ ) or the protein generated does not function (type $2 \mathrm{HAE}$ ) [3]. The disease progresses with episodes of angioedema that affect the respiratory system and may be life-threatening. Angioedema attacks can be induced by physical trauma, including invasive medical or surgical procedures [4]. Clinical guidelines for management of HAE recommend short-term prophylaxis before performing these procedures. The type of prophylaxis depends on the procedure (major or minor) and the patient $[5,6]$. There is no previous published experience of management of HAE C1-INH in patients who require ECT. Therefore, the technique has not been classified as a minor or a major procedure.

We present our experience in the management of a 57-yearold woman with HAE who was prescribed ECT for major depression. The patient was referred to the Allergy Department of Hospital Universitario Nuestra Señora de Candelaria, Tenerife, Spain in 2004 because of monthly episodes of swelling in her feet and hands since she was 16. In addition, she had experienced repeated episodes of abdominal pain, and laparotomy revealed no significant findings.

C1-INH levels and activity were below normal values in at least 2 determinations, and a diagnosis of HAE was established. Treatment with stanozolol $2 \mathrm{mg}$ daily was initiated, and the patient's condition gradually improved. The frequency and severity of the attacks decreased considerably to $\leq 1$ mild episode per year, with no need to visit the emergency department or receive purified $\mathrm{C} 1-\mathrm{INH}$. 
In 2008, the patient was diagnosed with depression in the psychiatry department. She received several drugs, but her status worsened and progressed to treatment-refractory major depression. ECT was recommended.

ECT procedures were performed under the constant supervision of a psychiatrist, anesthesiologist, and allergist. After ECT, the patient was admitted to the postanesthesiology area for a 10-hour observation period. Purified C1-INH was always on hand.

ECT was initially considered a major procedure because of our lack of experience and the absence of previous medical reports in a Medline search. The dose of stanozolol was increased to $2 \mathrm{mg}$ tid for 5 days before the procedure. The patient continued with this dose while she was receiving ECT. For the first procedure, she was admitted to hospital and received 2 doses (1000 IU and 500 IU) of purified C1INH (Berinert, CLS Behring) 6 hours and 30 minutes before ECT. Additional doses of C1-INH were always available in the operating room and in the recovery area. After ECT, the patient was admitted to the postanesthesiology area. She was discharged home after an observation period of 10 hours. There were no incidents during the procedure or at home. Therefore, we decided that the procedure could be considered low-risk. The dose of purified C1-INH was reduced. For the second procedure, she received only 1 dose of C1-INH (500 mg) 30 minutes before the ECT. There were no incidents.

The third procedure was carried out without purified $\mathrm{C} 1$. No incidents were reported. The following procedures were also carried out with a single 500-mg dose of C1-INH 30 minutes before the ECT. Again, no incidents were reported. The patient received 1 session each week for a total of 8 sessions.

Once the patient's psychiatrist decided to finish ECT, we decreased the dose of stanozolol again to $2 \mathrm{mg}$. No subsequent incidents were reported.

ECT is considered a risky procedure. It is performed under general anesthesia owing to the possibility of trauma during surgery. The most common complications are cardiovascular respiratory events, trauma, agitation, confusion, headache, nausea, and vomiting [7]. We were unable to find previous reports of patients diagnosed with HAE who have received ECT. ECT can trigger angioedema attacks. Initially, we considered the procedure to be high-risk, similar to major surgery [4]. However, given the absence of complications during the initial sessions, we considered ECT a minor procedure and did not administer purified C1-INH. The result was satisfactory in terms of control of symptoms and prevention of angioedema attacks.

In conclusion, ECT can be considered a low-risk procedure in patients with optimal disease control. It is useful to increase the doses of the patient's usual treatment, as in a minor procedure. C1-INH should be available in the room where the procedure is performed. Given the lack of experience with this type of patient, the use of C1-INH should be individualized to prevent angioedema attacks.

\section{Funding}

The authors declare that no funding was received for this study.

\section{Conflicts of Interest}

The authors declare that they have no conflicts of interest.

\section{Previous Presentation}

This article was presented in poster form at the Simposio Internacional de Urticaria Crónica (SEAIC), Sevilla, Spain 2015.

\section{References}

1. Lisanby SH. Electroconvulsive therapy for depression. N Engl J Med. 2007 Nov 8;357(19):1939-45.

2. Haq AU, Sitzmann AF, Goldman ML, Maixner DF, Mickey BJ. Response of depression to electroconvulsive therapy: a meta-analysis of clinical predictors. J Clin Psychiatry. 2015 Oct;76(10):1374-84.

3. Caballero $T$, Baeza ML, Cabañas R, Campos A, Cimbollek $S$, Gómez-Traseira C, González Quevedo T, Guilarte M, JuradoPalomo J, Larco Jl, López-Serrano MC, López-Trascasa M, Marcos C, Muñoz-Caro JM, Pedrosa M, Prior N, Rubio M, SalaCunill A. Consensus Statement on the Diagnosis, Management, and Treatment of Angioedema Mediated by Bradykinin. Part I. Classification, Epidemiology, Pathophysiology, Genetics, Clinical Symptoms, and Diagnosis. J Invest Allergol Clin Immunol. 2011;21(5):333-47.

4. Caballero $T$, Baeza ML, Cabañas R, Campos A, Cimbollek $S$, Gómez-Traseira C, González Quevedo T, Guilarte M, JuradoPalomo J, Larco Jl, López-Serrano MC, López-Trascasa M, Marcos C, Muñoz-Caro JM, Pedrosa M, Prior N, Rubio M, SalaCunill A. Consensus Statement on the Diagnosis, Management, and Treatment of Angioedema Mediated by Bradykinin. Part II. Treatment, Follow-up, and Special Situations. J Invest Allergol Clin Immunol. 2011;21(6):422-41.

5. Gómez-Traseira C, Pérez-Fernández E, López-Serrano $M C$ García-Ara MC, Pedrosa M, López-Trascasa M, Caballero T. Clinical Pattern and Acute and Long-term Management of Hereditary Angioedema Due to C1-Esterase Inhibitor Deficiency. J Invest Allergol Clin Immunol. 2015;25(5):358-64.

6. Fabiani J, Valle SO, Olivares M, Nieto $S$, Hernández Landeros E, Ginaca A, Bezrodnik L, Nievas E, Oleastro M, Barrera OM, Gallardo AM, King A, Rodriguez Galindo J, Ochoa Carabantes MJ, Craig T, Martinez Alfonso M, Montenegro C, Sevciovic Grumach A. Improving Care of Hereditary Angioedema With C1 Inhibitor Deficiency (Type 1 and Type 2 Hereditary Angioedema) in LatinAmerica. J Invest Allergol Clin Immunol. 2014;24(6):439-62.

7. Craig TJ, Bernstein JA, Farkas H, Bouillet L, Boccon-Gibod I. Diagnosis and Treatment of Bradykinin-Mediated Angioedema: Outcomes from an Angioedema Expert Consensus Meeting. Int Arch Allergy Immunol. 2014;165:119-27.

- Manuscript received November 27, 2015; accepted for publication January 7, 2016

Ariel Callero Viera

Ctra. General del Rosario, 145 38010 Santa Cruz de Tenerife, Spain Email: arielcallero@hotmail.com 


\section{Nonoccupational Airborne-Induced Anaphylaxis Caused by Anisakis simplex}

Barbarroja-Escudero J, Sanchez-Gonzalez MJ, Antolin-Amerigo $\mathrm{D}$, Rodriguez-Rodriguez M, Alvarez-Mon M

Servicio de Enfermedades del Sistema Inmune-Alergia, Hospital Universitario Príncipe de Asturias; Departamento de Medicina y Especialidades Médicas, Universidad de Alcalá, Alcalá de Henares, Madrid, Spain

J Investig Allergol Clin Immunol 2016; Vol. 26(3): 196-197 doi: 10.18176/jiaci.0055

Key words: Anaphylaxis. Anisakis simplex. Airborne. Nonoccupational.

Palabras clave: Anafilaxia. Anisakis simplex. Aerotransportado. No ocupacional.

Anisakis simplex, a parasitic nematode found in fish and cephalopods, causes a wide spectrum of clinical conditions, including occupational respiratory diseases, contact dermatitis, and anaphylaxis [1-4]. Anaphylaxis due to airborne exposure is relatively uncommon and only a few etiological agents have been described so far. These include worms, latex, o-(benzotriazol-1-yl)-N,N,N9,N9-tetramethyluronium hexafluorophosphate (HBTU), peanuts, cow's milk, fish, and common fig [5-9]. Anisakis has been described as an occupational cause of airborne anaphylaxis [10], but no cases of non-occupational anaphylaxis triggered by airborne exposure to this allergen have yet been described.

We report the case of a 36-year-old nonatopic woman, working as a cleaner, who had experienced urticaria and angioedema after eating fresh anchovy for several years. She had also had 1 episode of contact urticaria after touching fresh mussel shells. In 2009, she developed rhinoconjunctivitis followed by generalized pruritus, tongue edema, cough, dyspnea, and dizziness while standing on the street, just in front of a fish store. The episode resolved spontaneously in about 60 minutes. This systemic reaction has reoccurred on many occasions following different airborne exposures, such as standing in front of a fish store, handling fish, and/or inhaling vapors during the cooking of fish. She reported that she had never experienced any reactions on eating frozen, fresh, or cooked fish or shellfish. She had, however, avoided eating all seafood since she had experienced her last systemic reaction. She worked as a cleaner in public buildings and to her knowledge had never come in contact with fish or fish vapors potentially infested with Anisakis while working. A specific allergological work-up was performed.

Skin prick tests (SPTs) were performed with a standard series of aeroallergens (house dust mites, fungal spores, grass, weed and tree pollens, cat, and dog dander), food allergens (Anisakis, milk, egg, cereals, fruits, nuts, vegetables, legumes, and lipid transfer protein), and latex (ALK-Abelló, Madrid, Spain). The positive and negative controls used were histamine $(10 \mathrm{mg} / \mathrm{mL})$ and phenolated glycerol saline, respectively. A reaction with a hive diameter greater than $3 \mathrm{~mm}$ compared with the negative control was considered positive [3]. The SPTs were positive only to Anisakis. The rest of the anaphylaxis protocol was negative, including stool tests for parasites and hydatidosis serology. Considering the contact urticaria the patient had experienced after touching fresh mussel shells, we also performed a series of tests to rule out allergies other than Anisakis. These included SPTs and prick to prick tests with different fish and shellfish (hake, sole, cod, sardine, anchovy, salmon, tuna, squid, shrimp, clam, mussel, and oyster). The results were negative in all cases. Serum specific $\operatorname{IgE}(\mathrm{s} \operatorname{IgE})$ against fish, crustaceans, molluscs (including mussel), and latex were less than $0.10 \mathrm{kU}_{\mathrm{A}} / \mathrm{L}$ (negative, $<0.35 \mathrm{kU}_{\mathrm{A}} / \mathrm{L}$ ) (ImmunoCAP, Thermo Fisher Scientific). However, sIgE against clam was positive $\left(5.97 \mathrm{kU}_{\mathrm{A}} / \mathrm{L}\right.$ ), with a total $\mathrm{IgE}$ of $7490 \mathrm{IU} / \mathrm{mL}$ (normal, $<100 \mathrm{IU} / \mathrm{mL}$ ); Anisakis sIgE was over $100 \mathrm{kU}$ A $/ \mathrm{L}$ (Table). sIgE levels to tropomyosins (Pen a 1, Der p 10) and parvalbumins (Gad c 1, Cyp c 1) were $0.01 \mathrm{kU}_{\mathrm{A}} / \mathrm{L}$. To investigate possible crossreactivity between Anisakis and Ascaris and the high total serum $\mathrm{IgE}$ detected, we performed serum sIgE determination against Ascaris, which was negative $\left(<0.10 \mathrm{kU}_{\mathrm{A}} / \mathrm{L}\right)$. Serum baseline tryptase levels were 5.7 and $6.1 \mu \mathrm{g} / \mathrm{L}$ (normal, $<11.4 \mu \mathrm{g} / \mathrm{L}$ ). Oral food challenges with hake, sole, tuna, squid, shrimp, mussel, and clam under anti-Anisakis conditions (frozen at $-20^{\circ} \mathrm{C}$ for at least 48 hours) were well tolerated. We therefore ruled out fish and shellfish allergy.

The positive SPT to Anisakis and the repeatedly positive sIgE against Anisakis over 4 years confirmed sensitization to this nematode (Table). Nevertheless, allergy to Anisakis is overdiagnosed, and to further assess a direct link between exposure to Anisakis and the patient's symptoms, we performed a specific inhalation challenge (SIC). We placed the patient in a $70-\mathrm{m}^{3}$ room where a volunteer manipulated trays containing different fresh fish species, resembling a real situation in a fish store. Two additional volunteers (1 atopic and 1 nonatopic) served as controls; they were placed next to the patient, and all 3 were at a distance of 2 meters from the volunteer handler. Informed consent was obtained from all 4 people prior to the SIC. After 5 minutes of exposure, our patient developed intense sneezing, rhinorrhea, conjunctivitis, and a pruritic micropapular erythema on her face. Intramuscular 6-methyl-prednisolone and dexchlorpheniramine were administered immediately, and the symptoms disappeared completely in 30 minutes. Neither of the control volunteers showed symptoms. The only occupational case of Anisakis-induced anaphylaxis described so far was established without an SIC [10]. The patient was a woman working in a frozen-fish factory who developed symptoms after handling fish and inhaling fish cooking vapors. These symptoms disappeared immediately on removing the source of occupational exposure. The episode of contact urticaria experienced by our patient after touching fresh mussel shells was attributed to direct contamination by Anisakis-infested fish that could have come into contact with these shells in the fish store. Finally, eosinophil values were not associated with IgE levels against Anisakis (Table). If the patient had had a concomitant parasitic infection, these values should have been altered.

The recurrence rate of anaphylaxis is 2 to 3 times lower in the case of anaphylaxis without an associated atopic disease (Anisakis and drugs) than in anaphylaxis with such a disease (food, latex, and exercise) [4]. This is because the former is 
Table. Chronological Data Showing Serum Total lgE, Specific lgE against Anisakis, and Peripheral Blood Eosinophil Levels (\% and cells/mm³)

\begin{tabular}{|c|c|c|c|c|}
\hline Date of Blood Test & $\begin{array}{l}\text { Serum Total } \\
\operatorname{IgE}(\mathrm{IU} / \mathrm{mL})\end{array}$ & $\begin{array}{c}\text { Serum Specific IgE } \\
\text { Against Anisakis }\left(\mathrm{kU}_{\mathrm{A}} / \mathrm{L}\right)\end{array}$ & $\begin{array}{l}\text { Peripheral Blood } \\
\text { Eosinophils (\%) }\end{array}$ & $\begin{array}{c}\text { Peripheral Blood } \\
\text { Eosinophils }\left(\text { cells } / \mathrm{mm}^{3}\right)\end{array}$ \\
\hline 30 December 2009 & 7490 & $>100$ & 9.2 & 690 \\
\hline 9 April 2010 & 2850 & $>100$ & 6.4 & 550 \\
\hline 9 November 2010 & 715 & 99.7 & 4.1 & 390 \\
\hline 24 June 2011 & 530 & 55.7 & 7.7 & 600 \\
\hline 21 February 2013 & 346 & 47.6 & 5.7 & 510 \\
\hline 4 April 2013 & 238 & 25.7 & 6.0 & 530 \\
\hline 25 June 2013 & 291 & 20.2 & 7.9 & 620 \\
\hline 4 July 2013 & 353 & 19.0 & 5.6 & 500 \\
\hline 24 September 2013 & 302 & 21.4 & 5.3 & 470 \\
\hline 4 December 2013 & 290 & 18.0 & 7.3 & 580 \\
\hline 20 June 2014 & 229 & 12.5 & 6.7 & 600 \\
\hline 6 February 2015 & 240 & 10.7 & 4.4 & 490 \\
\hline
\end{tabular}

easier to avoid. Our case differs in this respect as avoidance of exposure to Anisakis proved less effective than avoidance of ingestion. Nevertheless, in August 2013, our patient experienced generalized urticaria and dyspnea after eating toast that had been prepared on a griddle contaminated with fish. She had been instructed in the use of epinephrine as needed. This accidental dietary transgression would explain the small increase observed in serum specific IgE against Anisakis, breaking the sequential decrease observed in figures over time (Table).

We have presented an exceptional case of anaphylaxis due to nonoccupational airborne exposure to Anisakis in a patient who was shown to have good tolerance to different fish and shellfish in several oral food challenge tests conducted under antiAnisakis conditions. To our knowledge, this is the first report of nonoccupational airborne-induced anaphylaxis caused by Anisakis.

\section{Acknowledgments}

This work was partially supported by a grant from Comunidad de Madrid MITIC-CM (S2010/BMD-2502), Spain

\section{Funding}

The authors declare that no funding was received for the present study.

\section{Conflicts of Interest}

The authors declare that they have no conflicts of interest.

\section{Previous Presentations}

This work was presented in part, in abstract and poster form, at the European Academy of Allergology and Clinical Immunology (June 2014, Copenhagen, Denmark).

\section{References}

1. Añíbarro B, Seoane FJ. Occupational conjunctivitis caused by sensitization to Anisakis simplex. J Allergy Clin Immunol. 1998;102:331-2.
2. Armentia A, Lombardero M, Callejo A, Martín Santos JM, Gil FJ, Vega J, Arranz ML, Martínez C. Occupational asthma by Anisakis simplex. J Allergy Clin Immunol. 1998;102:831-4.

3. Ventura MT, Tummolo RA, Di Leo E, D'Ersasmo M, Arsieni A. Immediate and cell-mediated reactions in parasitic infections by Anisakis simplex. J Investig Allergol Clin Immunol. 2008;18:253-9.

4. Alonso MA, García MV, Hernández JE, Moro MM, Ezquerra PE, Ingelmo AR, Albelda CV. Recurrence of anaphylaxis in a Spanish series. J Investig Allergol Clin Immunol. 2013;23:383-91.

5. Freye $H B$, Esch RE, Litwin CM, Sorkin L. Anaphylaxis to the ingestion and inhalation of Tenebrio molitor (mealworm) and Zophobas morio (superworm). Allergy Asthma Proc. 1996;17:215-9.

6. Eckhout GV Jr, Ayad S. Anaphylaxis due to airborne exposure to latex in a primigravida. Anesthesiology. 2001;95:1034-5.

7. Hannu T, Alanko K, Keskinen H. Anaphylaxis and allergic contact urticaria from occupational airborne exposure to HBTU. Occup Med. (Lond) 2006;56:430-3.

8. Leonardi S, Pecoraro R, Filippelli M, Miraglia del Giudice M, Marseglia G, Salpietro C, Arrigo T, Stringari G, Ricò S, La Rosa $\mathrm{M}$, Caffarelli C. Allergic reactions to foods by inhalation in children. Allergy Asthma Proc. 2014;35:288-94.

9. Macías EM, Sierra-Salgado O, Bartolomé B, Pastor-Vargas C, Muñoz-Bellido FJ, Dávila I. First case of airborne-induced anaphylaxis triggered by fruit. Ann Allergy Asthma Immunol. 2015;115:160-1.

10. Scala E, Giani M, Pirrotta L, Guerra EC, Cadoni S, Girardelli CR, De Pità O, Puddu P. Occupational generalised urticaria and allergic airborne asthma due to Anisakis simplex. Eur J Dermatol. 2001;11:249-50. Manuscript received November 1, 2015; accepted for
publication, January 27, 2016.

José Barbarroja-Escudero Carretera Madrid-Barcelona Km 33.600 28805 Alcalá de Henares (Madrid) Spain E-mails: jose.barbarroja@gmail.com; jose.barbarroja@uah.es 


\section{Personality Traits May Influence the Severity of Atopic Dermatitis in Adult Patients: A Pilot Study}

\author{
Lopes $C^{1,2}$, Pinto $L^{1,3,4}$, Leite $C^{1}$, Delgado $L^{1,3,5}$, Moreira $A^{1,5}$, \\ Lourinho $\mathrm{I}^{6}$ \\ ${ }^{1}$ Laboratory of Immunology, Basic and Clinical Immunology \\ Unit, Faculty of Medicine, University of Porto, Porto, Portugal \\ ${ }^{2}$ Immunoallergology Unit, Hospital Pedro Hispano, Matosinhos, \\ Portugal \\ ${ }^{3}$ Center for Health Technology and Services Research- \\ CINTESIS, Porto, Portugal \\ ${ }^{4}$ Department of Health and Decision Sciences - CIDES, Faculty \\ of Medicine, University of Porto, Porto, Portugal \\ ${ }^{5}$ Centro Hospitalar São João, Porto, Portugal \\ ${ }^{6}$ Department of Medical Education and Simulation, Faculty of \\ Medicine of the University of Porto, Porto, Portugal
}

J Investig Allergol Clin Immunol 2016; Vol. 26(3): 198-199 doi: 10.18176/jiaci.0056

Key words: Atopic dermatitis. Personality.

Palabras clave: Dermatitis atópica. Personalidad.

Atopic dermatitis (AD) is a recurring inflammatory skin disease that tends to be more severe when it persists into adulthood, with a considerable impact on the quality of life of patients and their families [1]. Its pathogenesis is complex and involves skin barrier impairment and innate and $\mathrm{T}_{\mathrm{H}} 2$-driven immunological deregulation [1]. Psychological factors may play a pivotal role in the manifestations of $\mathrm{AD}$, since symptoms of distress potentiate the release of pruritogenic neuromediators and trigger skin inflammation [2]. Personality traits, defined as the way an individual thinks, feels, and behaves, modulate the way patients minimize or tolerate stress or conflicts (coping strategies) [3]. A previous meta-analysis in other chronic diseases found an association between higher scores for personality traits (eg, extraversion, conscientiousness, and openness) and more engagement coping, in contrast with higher scores on neuroticism, which indicate a tendency toward inadequate disease management [4]. In parallel, patients with chronic skin diseases such as psoriasis and AD seem to have distinct personality profiles [5]. In the case of $\mathrm{AD}$, it is not known whether personality traits influence disease severity in a real-life setting.

In this pilot study, we assessed the relationship between the 5 main domains of personality traits and the objective severity of $\mathrm{AD}$ in adult patients with chronic disease.

We performed a cross-sectional analysis of patients aged $>16$ years with a medical diagnosis of $\mathrm{AD}$ according to the criteria of Hanifin and Rajka. Patients attending hospital visits were invited to participate. The severity of AD was assessed using the SCORing Atopic Dermatitis (SCORAD) index (0-103), and personality traits were assessed using the short version of the NEO Personality Inventory (NEO-PI-R) [6], which has been validated in the Portuguese population [7]. NEO-PI-R is a 60 -item multiple-choice questionnaire used to evaluate the 5 main dimensions of personality: neuroticism (measure of emotional stability), openness (predisposition to new experiences), extraversion (the main energy focus being held in- or outwards), agreeableness (the ability to deal with others), and conscientiousness (the sense of right and wrong with respect to one's own behaviour). The local ethics committee approved the study, and all the participants gave their informed consent. Participants with severe skin disease other than $\mathrm{AD}$, secondary infection (bacterial, fungal, or viral), or any major systemic disease were excluded. Sample size calculations were performed to determine the number of participants needed to detect effect sizes based on minimal clinically important differences in the SCORAD index: 42 patients were needed to detect a difference with a 2-tailed .05 significance level and a probability of $81 \%$ if the true difference in SCORAD between groups was 8.7 units. Of the 78 patients invited, 46 agreed to participate during hospital visits. Two were excluded because of significant comorbidities (diabetes mellitus type 1 and multiple sclerosis). The data analyzed were from 44 patients (mean age, 30 [13] years; 61\% female; 77\% atopic) who had had $\mathrm{AD}$ for a mean of $16(10)$ years. Eleven patients $(25 \%)$ had mild AD, $18(41 \%)$ moderate $\mathrm{AD}$, and 15 (34\%) severe AD. The mean SCORAD was 44.9 (27.3). A 1-way ANOVA was applied, and a post hoc Bonferroni correction was performed when significant differences were detected.

We found that participants scoring high on conscientiousness had less severe disease than those scoring normal (mean [95\%CI] SCORAD of 31.17 [19.58-42.58] vs 56.16 [42.73-68.67]; $P=.039)$. No further differences were observed for neuroticism $(P=.960)$, extraversion $(P=.065)$, openness $(P=.722)$, or agreeableness $(P=.186)$ (Table).

The fact that personality traits can affect the severity of $\mathrm{AD}$ is a key finding of our study. In contrast with results from a previous experimental setting [8], we found that higher conscientiousness was associated with less severe disease. Conscientiousness is associated with being methodical, hardworking, efficient, and organized and focused on solving tasks effectively in a results-oriented fashion [3]. It has also been associated with a consistent protective effect, predicting lower risk for internalizing problems [4]. We hypothesize that this personality trait can enhance adherence to treatment and diminish the impact of stressful stimuli. We also observed that patients scoring simultaneously low in extraversion and high in neuroticism tended to have higher mean SCORAD values (data not shown), probably because of emotional instability dominated by vulnerability to experiences of anxiety and general distress.

Our study is subject to a series of limitations. First, its cross-sectional design prevents us from assessing the causal directionality of the associations. Second, the sample was small. Although the sample size was similar to that of previous studies $[9,10]$ and we managed to include an adequate number of patients according to our sample size calculation, we cannot exclude the possibility that the number of patients within each category was insufficient to generate statistically significant results. Third, although SCORAD is highly recommended as a measure of disease severity in clinical studies owing to its validation and reproducibility, it has the disadvantage of being dependent on the examiner's subjectivity. However, all the patients were evaluated by the same trained investigator to minimize this effect. Finally, the natural course of $\mathrm{AD}$, which is characterized by remissions and flares, makes it more difficult to evaluate the cross-sectional 
Table. Personality Traits and Severity of Atopic Dermatitis

\begin{tabular}{|c|c|c|c|c|c|}
\hline \multirow[b]{2}{*}{ Personality Trait } & \multirow[b]{2}{*}{ Category } & \multirow[b]{2}{*}{ No. $(\%)$ of Patients } & \multicolumn{3}{|c|}{ SCORAD } \\
\hline & & & Mean & $95 \% \mathrm{CI}$ & $P$ Value $^{\mathrm{a}}$ \\
\hline Neuroticism & $\begin{array}{l}\text { Low } \\
\text { Normal } \\
\text { High }\end{array}$ & $\begin{array}{c}9(20) \\
21(48) \\
14(32)\end{array}$ & $\begin{array}{l}47.21 \\
45.22 \\
44.23\end{array}$ & $\begin{array}{l}22.23-71.66 \\
32.54-57.27 \\
28.39-58.61\end{array}$ & .960 \\
\hline Extraversion & $\begin{array}{l}\text { Low } \\
\text { Normal } \\
\text { High }\end{array}$ & $\begin{array}{c}2(5) \\
18(40) \\
24(55)\end{array}$ & $\begin{array}{l}83.12 \\
37.14 \\
47.16\end{array}$ & $\begin{array}{c}-190.68 \text { to } 355.68 \\
24.95-49.72 \\
36.05-58.70\end{array}$ & .065 \\
\hline Openness & $\begin{array}{l}\text { Low } \\
\text { Normal } \\
\text { High }\end{array}$ & $\begin{aligned} 3 & (7) \\
25 & (57) \\
16 & (36)\end{aligned}$ & $\begin{array}{l}42.21 \\
48.43 \\
41.32\end{array}$ & $\begin{array}{c}-10.79 \text { to } 95.46 \\
35.03-60.57 \\
28.51-52.79\end{array}$ & .722 \\
\hline Agreeableness & $\begin{array}{l}\text { Low } \\
\text { Normal } \\
\text { High }\end{array}$ & $\begin{array}{l}13(30) \\
20(46) \\
12(24)\end{array}$ & $\begin{array}{l}55.13 \\
38.31 \\
48.12\end{array}$ & $\begin{array}{l}38.07-72.55 \\
27.65-48.93 \\
20.96-75.04\end{array}$ & .186 \\
\hline Conscientiousness & $\begin{array}{l}\text { Low } \\
\text { Normal } \\
\text { High }\end{array}$ & $\begin{array}{l}12(27) \\
20(45) \\
12(28)\end{array}$ & $\begin{array}{l}41.13 \\
56.16 \\
31.17\end{array}$ & $\begin{array}{l}22.43-58.74 \\
42.73-68.67 \\
19.58-42.58\end{array}$ & .035 \\
\hline
\end{tabular}

Abbreviations: SCORAD, SCORing Atopic Dermatitis.

${ }^{a}$ One-way ANOVA. Patients scoring very low and low or very high and high were grouped into low and high, respectively

relationship between disease severity and personality traits, which are structural characteristics.

Our study also has notable strengths. It was carried out in an outpatient setting with validated clinical outcomes, as previously suggested by other authors [8]. We applied the same psychological questionnaires that had been used in a recent European multicenter survey [10] and that were previously validated in the Portuguese population, thus facilitating future comparisons. Furthermore, ours is the first study to explore the relationship between personality traits and severity of $\mathrm{AD}$ in a clinical setting.

We conclude that personality traits can influence the severity of $\mathrm{AD}$ in adult patients with long-term disease. Longitudinal studies addressing the role of personality in attaining control of $\mathrm{AD}$ are needed to draw definitive conclusions. Psychological assessment and training in adaptive coping strategies to enhance self-control may benefit patients with chronic AD.

\section{Acknowledgments}

We are grateful to Alice Coimbra for language revision.

\section{Funding}

This study was partially supported by IJUP 2011/91 (Youth Investigation Projects of Porto University) and the $2^{\text {nd }}$ Dermis II project.

\section{Conflicts of Interest}

The authors declare that they have no conflicts of interest.

\section{References}

1. Flohr C, Mann J. New insights into the epidemiology of childhood atopic dermatitis. Allergy. 2014;69(1):3-16.

2. Montoro J, Mullol J, Jáuregui I, Dávila I, Ferrer M, Bartra J, del Cuvillo A, Sastre J, Valero A. Stress and allergy. J Investig Allergol Clin Immunol. 2009;19 Suppl 1:40-7.

3. Carver CS, Connor-Smith J. Personality and coping. Annu Rev Psychol. 2010;61:679-704.
4. Malouff JM, Thorsteinsson EB, Schutte NS. The relationship between the five-factor model of personality and symptoms of clinical disorders: a meta-analysis. J Psychopathol Behav Assess. 2005;27:101-14.

5. Takahashi H, Tsuji H, Honma M, Shibaki H, Nakamura S, Hashimoto Y, Takahashi M, Koike K, Takei A, Ishida-Yamamoto A, lizuka H. Japanese patients with psoriasis and atopic dermatitis show distinct personality profiles. J Dermatol. 2013 May; 40(5):370-3.

6. Costa PT, MacCrae RR, Psychological Assessment Resources I. Revised NEO Personality Inventory (NEO PI-R) and NEO FiveFactor Inventory (NEO FFI): Professional Manual: Psychological Assessment Resources; 1992.

7. Bertonquini $V$, Pais-Ribeiro J. Study of reduced forms of NEOPI-R. Psicologia Teoria Investigação e Prática 2006;11:85-102.

8. Schut C, Bosbach S, Gieler U, Kupfer J. Personality traits, depression and itch in patients with atopic dermatitis in an experimental setting: a regression analysis. Acta Derm Venereol. 2014;94(1):20-5.

9. Takaki H, Ishii Y. Sense of coherence, depression, and anger among adults with atopic dermatitis. Psychol Health Med. 2013;18(6):725-34.

10. Dalgard FJ, Gieler $U$, Tomas-Aragones $L$, Lien $L$, Poot $F$, Jemec GB, Misery L, Szabo C, Linder D, Sampogna F, Evers AW, Halvorsen JA, Balieva F, Szepietowski J, Romanov D, Marron SE, Altunay IK, Finlay AY, Salek SS, Kupfer J. The Psychological Burden of Skin Diseases: A Cross-Sectional Multicenter Study Among Dermatological Out-Patients in 13 European Countries. J Invest Dermatol. 2015 Apr;135(4):984-91.

Manuscript received October 29, 2015; accepted for publication February 12, 2016.

Cristina Lopes

Serviço de Imunologia, Faculdade de Medicina da Universidade do Porto Alameda Prof. Hernani Monteiro 4200-319 Porto, Portugal

E-mail: clabreu@med.up.pt 


\section{Anaphylactic Shock Caused by a Hidden Allergen in Blood Sausage}

Canabal J, Caballero T, Caminoa M, Fiandor A, Quirce S, Cabañas R

Department of Allergy, Hospital La Paz Institute for Health Research (IdiPAZ), Madrid, Spain

J Investig Allergol Clin Immunol 2016; Vol. 26(3): 200-201 doi: $10.18176 /$ jiaci.0057

Key words: Anaphylactic shock. Hidden allergen. Caraway. Immunoblotting.

Palabras clave: Shock anafiláctico. Alérgeno oculto. Alcaravea. Inmunotransferencia.

A 47-year-old woman was treated for anaphylactic shock in the emergency room. Upon waking, she experienced vomiting, diarrhea, severe itching on the palms and soles that became generalized, as well as erythema and wheezing dyspnea. The physical examination in the emergency room revealed low blood pressure (76/52 $\mathrm{mmHg}$ ), tachycardia, and hypophonesis. Treatment with intramuscular adrenaline, antihistamine, and intravenous corticosteroids led to a full recovery. The patient was referred to our allergy department. Her medical history revealed surgery for a pituitary microadenoma 15 years earlier. She had been diagnosed with allergic rhinoconjunctivitis induced by house dust mites and pollen and allergic asthma induced by dog epithelium 10 years earlier. In the 5 years preceding her visit, she had only experienced asthma symptoms occasionally when exposed to dogs. She reported itching of the mouth when eating pistachios.

Onset of anaphylactic shock was 4 hours after eating scrambled eggs, blood sausage, and tuna dumplings with tomato sauce for dinner. Nonallergic anaphylaxis was ruled out. After thorough questioning, drugs, physical exercise, and alcohol were ruled out as cofactors in this episode. Other causes of anaphylaxis such as drugs, gastroallergic anisakiasis, hydatid disease, and mastocytosis were excluded. Serum tryptase levels measured several weeks after the anaphylactic reaction were within the normal range $(5.6 \mu \mathrm{g} / \mathrm{L})$. Pheochromocytoma and carcinoid syndrome were also ruled out.

The ingredients listed on the blood sausage label were pork jowl, bacon, onion, pig's blood, and spices. The manufacturer provided us with a list of the spices (caraway, black pepper, paprika, cinnamon, nutmeg, clove, coriander, and marjoram). The results of skin prick tests (SPT) were positive to mugwort pollen (with a mean wheal diameter of $9 \mathrm{~mm}$ ), Cupressus arizonica pollen $(5 \mathrm{~mm})$, Lolium perenne pollen $(6 \mathrm{~mm})$, pine nut, pistachio, and cat and dog dander. The results were negative for cereal flours, peach lipid transfer protein (LTP), egg, Anisakis species, oregano, cinnamon, onion, mustard, paprika, black pepper, nutmeg, lupine, and coriander. SPT results using our in-house spice extracts $(10 \mathrm{mg} / \mathrm{mL}$ in phosphate-buffered saline) were positive for caraway $(4 \mathrm{~mm})$, coriander $(3 \mathrm{~mm})$, green aniseed $(3 \mathrm{~mm})$, cumin $(3 \mathrm{~mm})$, fennel (4 mm), histamine control (6 mm), and negative control $(0 \mathrm{~mm})$. Prick-by-prick tests were positive to caraway $(3 \mathrm{~mm})$ and negative to egg, raw and fried blood sausage, tomato sauce (all from the same brands as those consumed by the patient), cumin, clove, aniseed, and coriander. The results of SPT performed with all of the aforementioned extracts were negative in 5 nonatopic controls and in 5 atopic patients.

Total IgE was $47.90 \mathrm{kU} / \mathrm{L}$. Specific IgE measurements (ImmunoCAP, Thermo Fisher) were positive for $C$ arizonica, $L$ perenne, mugwort pollen $\left(2.4 \mathrm{kU}_{\mathrm{A}} / \mathrm{L}\right)$, and $\operatorname{dog}$ and cat dander. Measurements were negative to dog, cat, and bovine and porcine serum albumins. Determination of specific $\operatorname{IgE}$ (ImmunoCAP) to celery, aniseed, coriander, fennel, and caraway was negative in 2 tests. Specific IgE measurements using microarrayed allergens (ISAC, Thermo Fisher) indicated positive results (medium-high) to mugwort LTP, nArt v3 (1 ISU), nArt v 1 (2.2 ISU), grass pollen group 1, major allergens from $C$ arizonica, $\mathrm{rFel} \mathrm{d} \mathrm{1,} \mathrm{and} \mathrm{rCan} \mathrm{f} 1$. Determination of specific IgE to $\omega-5$ gliadin (rTri a 19), animal serum albumins, and the remaining allergens was negative. The patient later tolerated pig meat, onion, eggs, blood sausage without spices, lamb, and beef.

Allergenic proteins in caraway, coriander, and blood sausage were studied using IgE-immunoblotting and immunoblot-inhibition assays. Of the several allergenic bands observed, an IgE-binding band at $22 \mathrm{kDa}$ was prominent (Figure). IgE binding was not observed when the allergens were incubated with a control serum. Immunoblottinginhibition showed that $\operatorname{IgE}$ binding to caraway extract was inhibited when the patient's serum was preincubated with blood sausage and vice versa.

The patient was diagnosed with anaphylactic shock caused by caraway and coriander contained in blood sausage and sensitization to other spices from the Apiaceae family. Subsequently, spices from this family were eliminated from her diet, and she has had no further anaphylactic reactions in the 5 years since then.

We report a case of anaphylactic shock in a pollen-allergic patient caused by a hidden allergen, caraway, which was not included in the list of ingredients on the product label. The strong SPT positivity for mugwort pollen and the postprandial

IgE-Immunoblotting

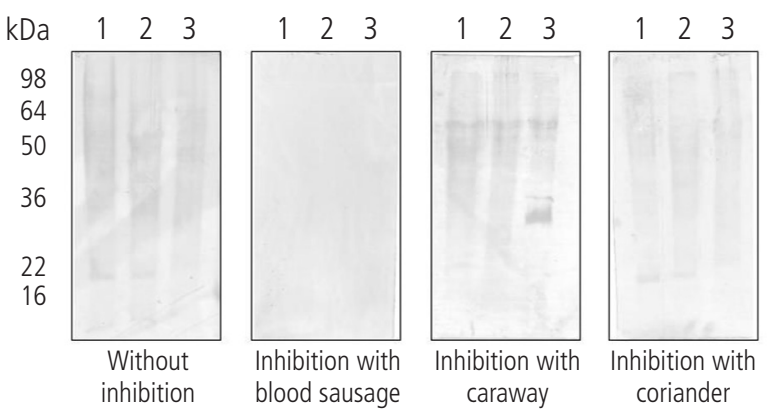

Figure. IgE-immunoblotting and immunoblotting-inhibition assays. Patient's serum incubated with extracts from blood sausage (lane 1), caraway (lane 2), and coriander (lane 3). 
systemic reaction raised clinical suspicion of a reaction to the spices [1] and aided us in our diagnosis despite the weak SPT positivity for known spices and the negative results of specific IgE determinations using ImmunoCAP. However, the patient was sensitized to mugwort LTP, a thermostable protein that is resistant to digestion and responsible for severe reactions. Blood sausage and caraway IgE immunoblots and immunoblot-inhibition showed several allergenic bands, especially the 22-kDa allergen. Previous studies on spices from the Apiaceae family revealed allergenic components of $60 \mathrm{kDa}[2,3]$ and of 12 and $14 \mathrm{kDa}$ [3]. A homologous Bet $\mathrm{v} 1$ allergen and a profilin-related allergen have also been identified in several spices [2], and an LTP has been detected in fennel [4], parsley [5], and saffron [6]. To our knowledge, caraway allergens have not been previously identified.

Allergy to spices is uncommon, accounting for $2 \%$ of all food allergies and $6.4 \%$ of food allergies in adults [1]. Young adults sensitized to mugwort and birch are at risk of spice allergy [1]. Spices from the Apiaceae and Umbelliferae families, particularly aniseed, coriander, caraway, and celery, can induce severe allergic systemic reactions. Small amounts of proteins are able to produce a reaction.

Extensive allergenic cross-reactivity between species from the Apiaceae family is common. Cross-reactivity between food spices belonging to the Umbelliferae family and pollens from the Compositae family has been reported [7]. Celerymugwort-spice syndrome is a well-known example of pollen cross-reactivity with spices $[8,9]$. However, our patient was not sensitized to celery. Allergy to serum albumins from animals, which contain proteins that are allergens in various mammalian products, was also ruled out.

In pollen-allergic patients who are sensitized to mugwort, the role of spices in food allergies should be assessed, especially in postprandial reactions [1], bearing in mind that they may be hidden allergens. We present a case of anaphylaxis to blood sausage in which caraway allergens were hidden. Caraway allergens have not been isolated to date, and further studies are necessary to better characterize them.

\section{Funding}

The authors declare that no funding was received for the present study.

\section{Conflicts of Interest}

The authors declare that they have no conflicts of interest.
4. Asero R, Mistrello G, Roncarolo D, Amato S. Detection of some safe plant-derived foods for LTP-allergic patients. Int Arch Allergy Immunol. 2007; 144:57-63.

5. Cordobés-Durán C, García-Menaya JM, Lombardero $M_{\text {, }}$ Ledesma A, Bobadilla P. Detection of a 12-kilodalton lipid transfer protein allergen in parsley. J Investig Allergol Clin Immunol. 2007;17(4):277-85.

6. Gómez-Gómez L, Feo-Brito F, Rubio Moraga A, Galindo PA, Prieto A, Ahrazem O. Involvement of lipid transfer proteins in saffron hypersensitivity: molecular cloning of the potential allergens. J Investig Allergol Clin Immunol. 2010;20(5):40712.

7. Pérez Bustamante $S$, Alvarez-Perea A, De Barrio M, Tomás M, Luisa Baeza M, Bartolomé-Zavala B. Allergy to curry: case report. Allergol Immunopathol (Madr). 2011;39:383-5.

8. Ebner $C$, Jensen-Jarolim $E$, Leitner $A$, Breiteneder $H$. Characterization of allergens in plant-derived spices: Apiaceae spices, pepper (Piperaceae), and paprika (bell peppers, Solanaceae). Allergy. 1998;53(46 Suppl):52-4.

9. García-González JJ, Bartolomé-Zavala B, Fernández-Meléndez S, Barceló-Muñoz JM, Miranda Páez A, Carmona-Bueno MJ, Vega-Chicote JM, Negro Carrasco MA, Ameal Godoy A, Pamies Espinosa R. Occupational rhinoconjunctivitis and food allergy because of aniseed sensitization. Ann Allergy Asthma Immunol. 2002;88:518-22.

Manuscript received August 6, 2015; accepted for publication February 17, 2016.

Rosario Cabañas

Department of Allergy

Hospital La Paz

po Castellana, 261

28046 Madrid, Spain

E-mail: charo.cabanas@gmail.com

\section{References}

1. Moneret-Vautrin DA, Morisset $M$, Lemerdy $P$, Croizier $A$, Kanny G. Food allergy and IgE sensitization caused by spices: CICBAA data (based on 589 cases of food allergy). Allerg Immunol (Paris). 2002:34:135-40.

2. Jensen-Jarolim E, Leitner $A$, Hirschwehr R, Kraft D, Wüthrich B, Scheiner O, Graf J, Ebner C. Characterization of allergens in Apiaceae spices: anise, fennel, coriander and cumin. Clin Exp Allergy. 1997;27:1299-306.

3. Harada S, Matsunaga A, Miyachi R, Masaki T, Moriyama T. Two cases of apiaceae spice allergy. Arerugi. 2007;56:1515-21. 


\section{Sensitization to Minor Allergens Has a Direct Influence on the Outcome of Subcutaneous Immunotherapy in Olive-Allergic Patients}

Peñuelas E, Serrano P, Barasona MJ, Saiz V, Fernandez L, Moreno $\mathrm{C}$

Immunology-Allergy Unit, Reina Sofía University Hospital, Córdoba, Spain

J Investig Allergol Clin Immunol 2016; Vol. 26(3): 202-204 doi: 10.18176/jiaci.0059

Key words: Subcutaneous immunotherapy. Olea europaea. Minor allergens. Rhinitis. Asthma.

Palabras clave: Inmunoterapia subcutánea. Olea europaea. Alérgenos menores. Rinitis. Asma.

Olive pollen is a significant and complex source of allergens in southern Europe [1-2]. A study of 891 patients showed that, in areas with high olive pollen exposure, olive-allergic patients present not only specific $\operatorname{IgE}$ ( $\mathrm{s} I g \mathrm{E}$ ) to a major olive allergen (Ole e 1), but also significant levels of sIgE to minor allergens such as Ole e 7 and Ole e 9 [3]. One publication established an association between sensitization to these minor allergens and poor tolerance to specific immunotherapy, with patients sensitized to Ole e 7 or 9 showing a 2-fold greater risk of asthmatic symptoms than patients sensitized only to Ole e 1 [4]. Our objective was to determine how sensitization profile affects the outcome of immunotherapy, which, in terms of immune changes and effectiveness, is analyzed according to the patients' sensitization profile, namely, whether patients are sensitized to Ole e 1 only or to Ole e 1 and Ole e 7 and/or Ole e 9.

This noninterventional, open-label, parallel-group study was carried out with the approval of the local ethics committee. Written informed consent was obtained from all participants. The study population comprised 76 patients, who were included consecutively before the pollen season (20 monosensitized to Ole e 1 [Oe1 group] and 56 sensitized to Ole e 1 and Ole e 7 and/or Ole e 9 [Oe79 group]).

The inclusion criteria were age 5 to 55 years with a $\geq 2$-year clinical history of troublesome symptoms of allergic rhinoconjunctivitis with/without asthma symptoms during the olive pollen season and a positive result in skin testing and determination of sIgE to Olea europaea (ImmunoCAP, Thermo Fisher, $\left.\geq 0.35 \mathrm{kU}_{\mathrm{A}} / \mathrm{L}\right)$.

All patients received subcutaneous immunotherapy (SCIT) with a depot extract (Pangramin Plus Olea europaea, ALKAbelló, SA). The Ole e 1 content was $15 \mu \mathrm{g} / \mathrm{mL}$; that of Ole e 9 and Ole e 7 was $0.5 \mu \mathrm{g} / \mathrm{mL}$. The build-up phase comprised a cluster schedule of 4 weekly visits and 2 doses/visit.

The level of sIgE to the different allergens was tested using the ADVIA Centaur platform (Bayer HealthCare, Diagnostics Division) [5], which has previously been used in epidemiological studies [3]. Specific IgG4 (sIgG4) against Ole e 1, Ole e 9, and Ole e 7 was determined using ELISA.
sIgE and sIgG4 were measured at T0 (baseline), T1 (updosing completed), and at T2 and T3 (6 and 18 months of treatment). Nasal, ocular, and bronchial allergic symptoms and the use of rescue medication (a very simple protocol comprising loratadine and Symbicort as needed) were recorded daily for 4 weeks during 2 consecutive olive pollen seasons. Symptoms were graded from 0 to 3 according to severity. Loratadine was given 1 point/tablet and Symbicort 2 points/puff. Symptom and medication scores were calculated.

Adverse reactions to SCIT were recorded in accordance with the European Academy of Allergy and Clinical Immunology (EAACI) classification [6].

The demographic characteristics of both groups (Oe1 vs Oe79) were similar in terms of age and sex. Seventy percent of the patients in the Oel group had rhinitis with asthma and $30 \%$ rhinitis only; in the Oe79 group these percentages were $96.2 \%$ and $3.8 \%$, respectively $(P=.0042)$. The time since the onset of symptoms of the allergic disease was similar in both groups $(P=.3356)$.

The Table shows the changes in sIgE and sIgG4 to Ole e 1, 7, and 9 in both groups at T1, T2, and T3 compared with T0.

When the correlation between increases in $\operatorname{sgE}$ and increases in sIgG4 was analyzed for the 3 allergens, it was only statistically significant for Ole e 1 at T3 $\left(\mathrm{r}^{2}=0.51, P<.0001\right)$. The correlation was significant at T0, T2, and T3 for Ole e 7 $\left(\mathrm{r}^{2}=0.80, P<.0001 ; \mathrm{r}^{2}=0.81, P<.0001 ;\right.$ and $\left.\mathrm{r}^{2}=0.77, P<.0001\right)$ and for Ole e $9\left(\mathrm{r}^{2}=0.62, P<.0001 ; \mathrm{r}^{2}=0.82, P<.0001\right.$; and $\left.\mathrm{r}^{2}=0.86, P<.0001\right)$.

No statistical differences were found between the 2 groups for the symptom score at T2 or T3. In the case of the medication score, the Oel group needed less antiasthmatic medication than the Oe79 group at T2 $(P=.0184)$ and at T3 $(P=.0091)$.

Systemic reactions were more frequent in the Oe79 group. In the Oe 1 group, 16 reactions were recorded in 5 patients (all mild, delayed, grade I [EAACI]); in the Oe79 group, 35 reactions ( 31 grade I, 3 grade II, and 1 grade III, $75 \%$ delayed) were recorded in 28 patients. No serious adverse reactions were recorded, and no patients discontinued treatment owing to adverse reactions.

Given that more than 1 sensitization pattern is often observed in areas with an extended high allergen burden [7], Ole e 7 and Ole e 9 become major allergens. Componentresolved diagnosis enables individual sensitization and a better therapeutic approach for polysensitized patients [8-9]. The sIgE values for the components studied were always consistent with the kinetics observed in SCIT (initial elevation and subsequent decrease) [10] in each group, and IgG4 tended to behave as expected. Of note, in the Oe79 group, sensitization to Ole e 9 was always consistent with sensitization to Ole e 1, as were the changes associated with this sensitization. However, this was not the case for Ole e 7 .

The different sizes of the 2 subgroups are indicative of the population in a region with an extremely high concentration of olive pollen, in which Ole e 7 and Ole e 9 are major allergens associated with a high prevalence of asthma.

The present study could be considered a pilot study that demonstrated more than 1 form of olive pollen allergy. The consequences for routine clinical practice are the need to identify sensitization to minor allergens in areas with a 
Table. slgE and slgG4 to Ole e 1, Ole e 7, and Ole e 9

\begin{tabular}{|c|c|c|c|c|c|c|}
\hline & Visit & No. & Median & $\begin{array}{c}\text { 95\% CI, } \\
\text { Lower Limit }\end{array}$ & $\begin{array}{c}\text { 95\% CI, } \\
\text { Upper Limit }\end{array}$ & $P$ Value $^{\mathrm{a}}$ \\
\hline \multicolumn{7}{|l|}{ Group Oe1 } \\
\hline IgE Ole e $1, \mathrm{kU}_{\mathrm{A}} / \mathrm{L}$ & $\begin{array}{l}\mathrm{T} 1 \text { vs } \mathrm{T} 0 \\
\mathrm{~T} 2 \text { vs } \mathrm{T} 0 \\
\mathrm{~T} 3 \text { vs } \mathrm{T} 0\end{array}$ & $\begin{array}{l}20 \\
19 \\
18\end{array}$ & $\begin{array}{l}4.35 \\
5.02 \\
1.61\end{array}$ & $\begin{array}{c}1.48 \\
3.51 \\
-7.53\end{array}$ & $\begin{array}{l}14.54 \\
20.33 \\
18.11\end{array}$ & $\begin{array}{c}.0003 \\
<.0001 \\
.1415\end{array}$ \\
\hline IgG4 Ole e $1, \mathrm{mg} / \mathrm{L}$ & $\begin{array}{l}\mathrm{T} 1 \text { vs } \mathrm{T} 0 \\
\mathrm{~T} 2 \text { vs } \mathrm{T} 0 \\
\mathrm{~T} 3 \text { vs } \mathrm{T} 0\end{array}$ & $\begin{array}{l}20 \\
19 \\
18\end{array}$ & $\begin{array}{l}0.22 \\
0.43 \\
0.93\end{array}$ & $\begin{array}{l}0.12 \\
0.27 \\
0.54\end{array}$ & $\begin{array}{l}0.42 \\
0.83 \\
1.78\end{array}$ & $\begin{array}{l}<.0001 \\
<.0001 \\
<.0001\end{array}$ \\
\hline IgE Ole e $7, \mathrm{kU}_{\mathrm{A}} / \mathrm{L}$ & $\begin{array}{l}\mathrm{T} 1 \text { vs } \mathrm{T} 0 \\
\mathrm{~T} 2 \text { vs } \mathrm{T} 0 \\
\mathrm{~T} 3 \text { vs } \mathrm{T} 0\end{array}$ & $\begin{array}{l}20 \\
19 \\
18\end{array}$ & $\begin{array}{l}0.01 \\
0.04 \\
0.28\end{array}$ & $\begin{array}{c}-0.04 \\
-0.04 \\
1.41\end{array}$ & $\begin{array}{l}0.47 \\
1.72 \\
9.16\end{array}$ & $\begin{array}{r}.0256 \\
.0076 \\
.0005\end{array}$ \\
\hline IgG4 Ole e 7, mg/L & $\begin{array}{l}\mathrm{T} 1 \text { vs } \mathrm{T} 0 \\
\mathrm{~T} 2 \text { vs } \mathrm{T} 0 \\
\mathrm{~T} 3 \text { vs } \mathrm{T} 0\end{array}$ & $\begin{array}{l}20 \\
19 \\
18\end{array}$ & $\begin{array}{c}0 \\
0 \\
0.02\end{array}$ & $\begin{array}{c}-0.01 \\
-0.08 \\
0.14\end{array}$ & $\begin{array}{c}0.18 \\
0.4 \\
1.49\end{array}$ & $\begin{array}{l}.0195 \\
.0068 \\
.0002\end{array}$ \\
\hline IgE Ole e $9, \mathrm{kU}_{\mathrm{A}} / \mathrm{L}$ & $\begin{array}{l}\mathrm{T} 1 \text { vs } \mathrm{T} 0 \\
\mathrm{~T} 2 \text { vs } \mathrm{T} 0 \\
\mathrm{~T} 3 \text { vs } \mathrm{T} 0\end{array}$ & $\begin{array}{l}20 \\
19 \\
18\end{array}$ & $\begin{array}{l}0.01 \\
0.01 \\
0.02\end{array}$ & $\begin{array}{c}-0.33 \\
-0.62 \\
0.07\end{array}$ & $\begin{array}{c}1.09 \\
2.66 \\
7.3\end{array}$ & $\begin{array}{l}.1327 \\
.0728 \\
.1297\end{array}$ \\
\hline IgG4 Ole e $9, \mathrm{mg} / \mathrm{L}$ & $\begin{array}{l}\mathrm{T} 1 \text { vs } \mathrm{T} 0 \\
\mathrm{~T} 2 \text { vs } \mathrm{T} 0 \\
\mathrm{~T} 3 \text { vs } \mathrm{T} 0\end{array}$ & $\begin{array}{l}20 \\
19 \\
18\end{array}$ & $\begin{array}{c}0 \\
0 \\
0.01\end{array}$ & $\begin{array}{c}-0.01 \\
0 \\
-0.01\end{array}$ & $\begin{array}{l}0.03 \\
0.03 \\
0.21\end{array}$ & $\begin{array}{l}.7500 \\
.0625 \\
.0039\end{array}$ \\
\hline \multicolumn{7}{|l|}{ Group Oe79 } \\
\hline IgE Ole e $1, \mathrm{kU}_{\mathrm{A}} / \mathrm{L}$ & $\begin{array}{l}\text { T1 vs T0 } \\
\text { T2 vs T0 } \\
\text { T3 vs T0 }\end{array}$ & $\begin{array}{l}53 \\
52 \\
53\end{array}$ & $\begin{array}{c}1.79 \\
5.41 \\
0.6\end{array}$ & $\begin{array}{c}-2.99 \\
1.58 \\
-5.61\end{array}$ & $\begin{array}{c}11.49 \\
19.85 \\
6.81\end{array}$ & $\begin{array}{c}.0007 \\
<.0001 \\
.5376\end{array}$ \\
\hline IgG4 Ole e $1, \mathrm{mg} / \mathrm{L}$ & $\begin{array}{l}\mathrm{T} 1 \text { vs } \mathrm{T} 0 \\
\mathrm{~T} 2 \text { vs } \mathrm{T} 0 \\
\mathrm{~T} 3 \text { vs } \mathrm{T} 0\end{array}$ & $\begin{array}{l}53 \\
52 \\
53\end{array}$ & $\begin{array}{l}0.16 \\
0.39 \\
0.75\end{array}$ & $\begin{array}{l}0.15 \\
0.37 \\
0.61\end{array}$ & $\begin{array}{l}0.37 \\
0.72 \\
1.27\end{array}$ & $\begin{array}{l}<.0001 \\
<.0001 \\
<.0001\end{array}$ \\
\hline IgE Ole e $7, \mathrm{kU}_{\mathrm{A}} / \mathrm{L}$ & $\begin{array}{l}\mathrm{T} 1 \text { vs } \mathrm{T} 0 \\
\mathrm{~T} 2 \text { vs } \mathrm{T} 0 \\
\mathrm{~T} 3 \text { vs } \mathrm{T} 0\end{array}$ & $\begin{array}{l}53 \\
52 \\
53\end{array}$ & $\begin{array}{c}1.18 \\
10.09 \\
6.21\end{array}$ & $\begin{array}{c}5.32 \\
10.32 \\
5.11\end{array}$ & $\begin{array}{l}16.54 \\
22.31 \\
17.45\end{array}$ & $\begin{array}{l}<.0001 \\
<.0001 \\
<.0001\end{array}$ \\
\hline IgG4 Ole e 7, mg/L & $\begin{array}{l}\mathrm{T} 1 \text { vs } \mathrm{T} 0 \\
\mathrm{~T} 2 \text { vs } \mathrm{T} 0 \\
\mathrm{~T} 3 \text { vs } \mathrm{T} 0\end{array}$ & $\begin{array}{l}52 \\
52 \\
52\end{array}$ & $\begin{array}{l}0.61 \\
0.96 \\
1.98\end{array}$ & $\begin{array}{l}0.66 \\
0.73 \\
1.87\end{array}$ & $\begin{array}{c}1.61 \\
2.38 \\
4.4\end{array}$ & $\begin{array}{l}<.0001 \\
<.0001 \\
<.0001\end{array}$ \\
\hline IgE Ole e $9, \mathrm{kU}_{\mathrm{A}} / \mathrm{L}$ & $\begin{array}{l}\mathrm{T} 1 \text { vs } \mathrm{T} 0 \\
\mathrm{~T} 2 \text { vs } \mathrm{T} 0 \\
\mathrm{~T} 3 \text { vs } \mathrm{T} 0\end{array}$ & $\begin{array}{l}53 \\
52 \\
53\end{array}$ & $\begin{array}{l}2.26 \\
4.42 \\
0.22\end{array}$ & $\begin{array}{c}6.17 \\
7.76 \\
-0.92\end{array}$ & $\begin{array}{c}18.72 \\
23.03 \\
12\end{array}$ & $\begin{array}{c}<.0001 \\
<.0001 \\
.0119\end{array}$ \\
\hline IgG4 Ole e $9, \mathrm{mg} / \mathrm{L}$ & $\begin{array}{l}\mathrm{T} 1 \text { vs T0 } \\
\mathrm{T} 2 \text { vs T0 } \\
\mathrm{T} 3 \text { vs T0 }\end{array}$ & $\begin{array}{l}53 \\
52 \\
53\end{array}$ & $\begin{array}{l}0.09 \\
0.02 \\
0.19\end{array}$ & $\begin{array}{l}0.12 \\
0.11 \\
0.29\end{array}$ & $\begin{array}{l}0.44 \\
0.28 \\
0.67\end{array}$ & $\begin{array}{l}<.0001 \\
<.0001 \\
<.0001\end{array}$ \\
\hline
\end{tabular}

${ }^{\mathrm{a}}$ Wilcoxon signed rank test.

high environmental concentration and the need to choose immunotherapy extracts with a controlled and uniform content in terms of Ole e 1, Ole e 7, and Ole e 9.

Appropriately designed studies are required to determine the short- and long-term clinical response parameters in the different sensitization groups.

\section{Funding}

The authors declare that no funding was received for the present study.

\section{Conflicts of Interest}

The authors declare that they have no conflicts of interest.

\section{References}

1. Sánchez Mesa, JA, Brandao R, Lopes L, Galan C. Correlation between pollen counts and symptoms in two different areas of the Iberian Peninsula: Cordoba (Spain) and Evora (Portugal). J Investig Allergol Clin Immunol. 2005;15:112-6. 
2. Villalba $M$, Rodríguez $R$, Batanero $E$. The spectrum of olive pollen allergens. From structures to diagnosis and treatment. Methods. 2014;66:44-54.

3. Barber D, de la Torre F, Feo F, Florido F, Guardia P, Moreno C, Quiralte J, Lombardero M, Villalba M, Salcedo G, Rodríguez $R$. Understanding patient sensitization profiles in complex pollen areas: a molecular epidemiologic study. Allergy. 2008;63:1550-8.

4. Serrano P. Sensibilización a alérgenos menores de Olea europaea como causa de reacciones sistémicas por inmunoterapia alérgeno-específica. Doctoral Thesis, Córdoba. Facultad de Medicina, Universidad de Córdoba, 2007.

5. Barber D, Moreno C, Ledesma A, Serrano P, Galán A, Villalba M, Guerra F, Lombardero M, Rodríguez R. Degree of olive pollen exposure and sensitization patterns. Clinical implications. J Investig Allergol Clin Immunol. 2007;17:11-6.

6. Alvarez-Cuesta E, Bousquet J, Canonica GW, Durham SR, Malling HJ, Valovirta E. Standards for practical allergenspecific immunotherapy. Allergy. 2006;61 (Suppl.82):1-20.

7. Galan C, Antunes C, Brandao R, Torres C, García-Mozo H, Caeiro E, Ferro R, Prank M, Sofiev M, Albertini R, Berger $U$, Cecchi L, Celenk S, Jackoviak B, Jäger S, Kennedy R, RantioLehttimäki A, Reese $G$, Sauliene I, Smith $M$, Thibaudon $M$, Weber B, Weichenmeier I, Pusch G, Buters JT; HIALINE working group. Airborne olive pollen counts are not representative of exposure to the major olive allergen Ole e 1. Allergy. 2013;68:809-12.

8. Sastre J, Landivar ME, Ruíz-García M, Andregnette-Rosigno MV, Mahillo I. How molecular diagnosis can change allergenspecific immunotherapy prescription in a complex pollen area. Allergy. 2012;67:709-11.

9. Moreno C, Justicia JL, Quiralte J, Moreno-Ancillo A, IglesiasCadarso A, Torrecillas M, Labarta N, García MA, Dávila I. Olive, grass or both? Molecular diagnosis for the allergen immunotherapy selection in polysensitized pollinic patients. Allergy. 2014;69:1357-63.

10. Aasbjerg K, Backer V, Lund G, Holm J, Nielsen NC, Holse M, Wagtmann VR, Würtzen PA. Immunological comparison of allergen immunotherapy tablet treatment and subcutaneous immunotherapy against grass allergy. Clin Exp Allergy. 2013;44:417-28.

Manuscript received November 3, 2015; accepted for publication February 25, 2016.

Carmen Moreno

Head of Immunology-Allergy Unit Reina Sofía University Hospital

Córdoba

Spain

E-mail: carmen.moreno.aguilar@gmail.com

\section{The Smartphone: A Novel Diagnostic Tool in Pollen Allergy?}

Bianchi $\mathrm{A}^{1}$, Tsilochristou $\mathrm{O}^{2}$, Gabrielli $\mathrm{F}^{3}$, Tripodi $\mathrm{S}^{4}$, Matricardi $\mathrm{PM}^{2}$

${ }^{1}$ Pediatric Unit, Mazzoni Hospital, Ascoli Piceno, Italy

${ }^{2}$ Department of Pediatric Pneumology and Immunology, Charité Medical University, Berlin, Germany

${ }^{3}$ ARPAM, Aerobiological Monitoring Service, Castel di Lama (AP), Italy

${ }^{4}$ Pediatric Department and Pediatric Allergology Unit, Sandro Pertini Hospital, Rome, Italy

J Investig Allergol Clin Immunol 2016; Vol. 26(3): 204-207 doi: 10.18176/jiaci.0060

Key words: mHealth. Allergy. Rhinitis. Pollen. Mobile app.

Palabras clave: mHealth. Alergia. Rinitis. Polen. Aplicación móvil.

The diagnosis of pollen-induced allergic rhinitis (AR) is based on a thorough clinical history confirmed by positive results in testing with aeroallergens. Tests can be in vivo (skin prick test [SPT]) and in vitro (assays for determination of $\mathrm{IgE})$. The pollination season of the triggering allergens must coincide with the period during which the patient has the respiratory symptoms $[1,2]$. In allergy epidemics, however, most AR patients are sensitized to multiple aeroallergens. The etiological diagnosis of seasonal AR is therefore difficult, especially in geographic areas such as the Mediterranean, where many pollens have an overlapping pollination season. Component-resolved diagnosis is a molecular-based approach that can discriminate between sensitization to species-specific, genuine allergenic molecules and sensitization to highly crossreactive molecules (eg, profilins, polcalcins, and pathogenesisrelated 10 proteins) shared by various types of pollen [3]. Nonetheless, it cannot identify the trigger in patients sensitized to species-specific molecules of pollens with overlapping pollination periods.

The use of smartphones and electronic clinical diaries has introduced new possibilities for monitoring chronic diseases [4] such as hypertension, diabetes [5], and asthma [6]. In particular, web-based management of asthmatic patients is feasible, safe, and preferred by patients [6]. The use of smartphones has also become more common in allergology, and patient-centered systems have recently been developed to fill gaps in disease management by using information and communications technology tools and a clinical decision support system [7]. During the last few years, we have accumulated experience from the application of mobile health (mHealth) technology to monitor adherence to treatment of children with allergic rhinitis $[8,9]$. While mHealth is already being investigated as a monitoring tool, there are, to our knowledge, no reports in the literature indicating that it can assist in the diagnosis of AR. 
We report on 2 patients who were sensitized to multiple seasonal allergens with overlapping pollination periods and to whom a diagnostic solution was offered in the form of an mHealth monitoring app. The patients were asked to register their symptoms daily during May and June 2011 using a smartphone with a dedicated electronic clinical diary app (AllergyMonitor, TPS Production). This app records disease severity and symptom scores (eg, the Rhinoconjunctivitis Total Symptom Score [RTSS]) and enables them to be compared against locally relevant pollen counts. The patients and their parents were instructed in the use of the app by a pediatrician (AB), who spent about 10 minutes per patient on instruction. The data were entered into the app directly by the children, who were assisted by their parents. The pediatrician, however, had no direct control over this daily activity.

The patients were a 10 year-old boy and a 7-year-old boy, both of whom had had persistent moderate-severe AR from the age of 3 years. The children had been living in Ascoli Piceno, Marche, Italy since birth and reported having had rhinitis symptoms (stuffy, runny, and itchy nose with sneezing) for the previous 2 years, mainly during May and June. The results of SPTs with allergenic extracts (ALK-Abelló, Denmark) were positive (wheal diameter $\geq 3 \mathrm{~mm}$ ) in both cases for many pollens, including olive and timothy grass (Figure, A and B), whose pollination period in Ascoli Piceno is between April and June. Component-resolved diagnosis (UniCAP, TFS) performed using sera provided evidence of cosensitization (cutoff $\geq 0.35 \mathrm{kU}_{\mathrm{A}} / \mathrm{L}$ ) not only to the major allergenic molecules of olive (Ole e 1), timothy grass (Phl p 1, Phl p 5), and -in the first patient - pellitory (Par $\mathrm{j} 2$ ), but also to cross-reacting molecules (Phl p 12, profilin; Phl p 7, polcalcin) (Figure, $A$ and B). The pediatrician was unable to tailor therapy based on these data. Comparing the RTSS and the pollen counts on the app, the peak of the symptoms for the first patient coincided with the peak of the olive pollen counts (Figure, A), while for the second patient it coincided with peak grass pollen counts (Figure, B). Based on these data, the pediatrician was able to prescribe immunotherapy against olive pollen allergens in the first patient and grass pollen allergens in the second one.

Both cases present similar diagnostic challenges; no clear-cut decision could be reached using the traditional allergological evaluation with SPT or using the innovative molecular approach of determination of IgE against genuine and cross-reacting allergenic molecules. However, the prospective and consistent recording of nasal and conjunctival symptoms during the pollination season played a key role in the identification of the trigger pollen (olive pollen in the first case, grass pollen in the second). To our knowledge, this is the first report of an etiological diagnosis of pollen allergy substantiated by a smartphone app. Comparison between the RTSS and pollen curves can guide the physician when deciding on immunotherapy. The inclusion of medication use in the registration is important. The app AllergyMonitor enables the patient to record medication intake and calculates several symptom and medication scores (Florack et al, submitted).

Our report is subject to a series of limitations. First, our findings are based on 2 cases only, although larger studies are being planned to test the hypotheses generated here. Second, the patients' symptoms were monitored in 1 pollen

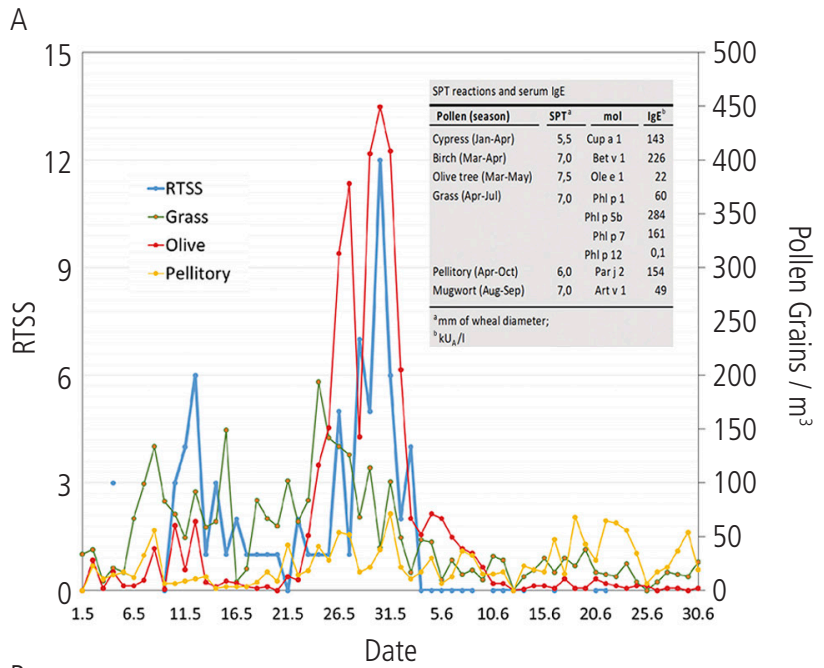

B

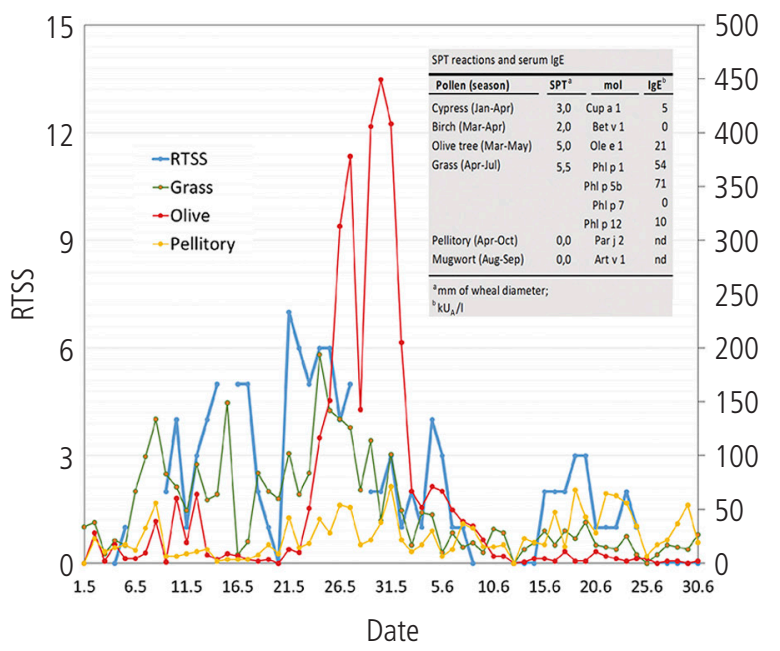

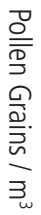

Figure. Symptom severity vs pollen counts in 2 patients with allergic rhinitis. Data on severity of symptoms (collected using a smartphone app) are reported as the Rhinoconjunctivitis Total Symptom Score (RTSS) (A, Patient 1; B, Patient 2). Pollen counts (grains $/ \mathrm{m}^{3}$ ) were obtained from the pollen station of Ascoli Piceno. Data on skin prick test reactions to pollen extracts and on serum IgE levels against major allergenic molecules are shown. We also measured the following serum lgE levels $\left(\mathrm{KU}_{\mathrm{A}} / \mathrm{L}\right)$ against pollen extracts: Patient 1, cypress 143, birch 226, olive tree 122, grass 404, pellitory 191, mugwort 96; Patient 2, cypress 2, birch 9, olive tree 24, grass 157

season only; longer follow-up covering consecutive springs is necessary. Third, some of the second patient's values were missing, although a statistical analysis performed after linear interpolation of the data confirmed the conclusions obtained before interpolation (findings not shown).

In conclusion, mHealth technology is increasingly used and has many potential benefits: a more precise clinical history, prospective recording of objective patient parameters, support for diagnostic and clinical decisions, better doctor-patient and doctor-doctor communication, monitoring of the safety of treatment and adherence, facilitation of implementation of guidelines, patient education and awareness, and reduced 
costs [4-9]. Our findings suggest that this novel, noninvasive diagnostic tool warrants further investigation in order to verify its usefulness and potential in the clinical diagnosis of pollenallergic patients.

\section{Acknowledgments}

We are grateful to TPS Production (Rome, Italy) for the use of their "AllergyMonitor" platform.

\section{Funding}

The authors declare that no funding was received for the present study.

\section{Conflicts of Interest}

Salvatore Tripodi is a cofounder and shareholder of TPS Production. The remaining authors declare that they have no conflicts of interest.

\section{References}

1. Bousquet J, Khaltaev N, Cruz AA, Denburg J, Fokkens WJ, Togias A, Zuberbier T, Baena-Cagnani CE, Canonica GW, van Weel C, Agache I, Aït-Khaled N, Bachert C, Blaiss MS, Bonini S, Boulet LP, Bousquet PJ, Camargos P, Carlsen KH, Chen $Y$, Custovic A, Dahl R, Demoly P, Douagui $H$, Durham SR, van Wijk RG, Kalayci O, Kaliner MA, Kim YY, Kowalski ML, Kuna P, Le LT, Lemiere C, Li J, Lockey RF, Mavale-Manuel S, Meltzer EO, Mohammad Y, Mullol J, Naclerio R, O'Hehir RE, Ohta K, Ouedraogo S, Palkonen S, Papadopoulos N, Passalacqua G, Pawankar R, Popov TA, Rabe KF, Rosado-Pinto J, Scadding GK, Simons FE, Toskala E, Valovirta E, van Cauwenberge P, Wang DY, Wickman M, Yawn BP, Yorgancioglu A, Yusuf OM, Zar H, Annesi-Maesano I, Bateman ED, Ben Kheder A, Boakye DA, Bouchard J, Burney P, Busse WW, Chan-Yeung M, Chavannes $\mathrm{NH}$, Chuchalin A, Dolen WK, Emuzyte R, Grouse L, Humbert M, Jackson C, Johnston SL, Keith PK, Kemp JP, Klossek JM, Larenas-Linnemann $D$, Lipworth $B$, Malo JL, Marshall GD, Naspitz C, Nekam K, Niggemann B, Nizankowska-Mogilnicka E, Okamoto Y, Orru MP, Potter P, Price D, Stoloff SW, Vandenplas O, Viegi G, Williams D; World Health Organization; GA(2) LEN; AllerGen. Allergic Rhinitis and its Impact on Asthma (ARIA) 2008 update (in collaboration with the World Health Organization, GA(2)LEN and AllerGen). Allergy. 2008;63 Suppl 86:8-160.

2. Dávila I, Navarro A, Domínguez-Ortega J, Alonso A, AntolínAmérigo $D$, Diéguez MC, González-Mancebo $E$, Martíns $C$, Martínez C, Núñez B, Prior N, Rechel M, Rosado A, RuizHornillos J, Sansosti A, Torrecillas M, Jerez MJ; QUASAR Group; QUality Administration of SLIT in Allergic Rhinitis. SLIT: indications, follow-up, and management. J Investig Allergol Clin Immunol. 2014;24 Suppl 1:1-35.

3. Stringari G, Tripodi S, Caffarelli C, Dondi A, Asero R, Di Rienzo Businco A, Bianchi A, Candelotti P, Ricci G, Bellini F, Maiello N, Miraglia del Giudice M, Frediani T, Sodano S, Dello lacono I, Macrì F, Peparini I, Povesi Dascola C, Patria MF, Varin E, Peroni $D$, Comberiati P, Chini L, Moschese V, Lucarelli S, Bernardini R, Pingitore G, Pelosi U, Tosca M, Cirisano A, Faggian D,
Travaglini A, Plebani M, Matricardi PM; Italian Pediatric Allergy Network (I-PAN). The effect of component-resolved diagnosis on specific immunotherapy prescription in children with hay fever. J Allergy Clin Immunol. 2014;134:75-81.

4. WHO 'mHealth New Horizons for health through mobile technologies' http://www.who.int/goe/publications/goe_ mhealth_web.pdf. Accessed 23/09/2015.

5. Hamine $S$, Gerth-Guyette E, Faulx D, Green BB, Ginsburg AS. Impact of mHealth chronic disease management on treatment adherence and patient outcomes: a systematic review. J Med Internet Res. 2015;17:e52.

6. Araújo L, Jacinto T, Moreira A, Castel-Branco MG, Delgado $L$, Costa-Pereira A, Fonseca J. Clinical efficacy of web-based versus standard asthma self-management. J Investig Allergol Clin Immunol. 2012;22:28-34

7. Bousquet J, Schunemann HJ, Fonseca J, Samolinski B, Bachert C, Canonica GW, Casale T, Cruz AA, Demoly P, Hellings $P$, Valiulis A, Wickman $M$, Zuberbier $T$, Bosnic-Anticevitch $S$, Bedbrook A, Bergmann KC, Caimmi D, Dahl R, Fokkens WJ, Grisle I, Lodrup Carlsen K, Mullol J, Muraro A, Palkonen S, Papadopoulos N, Passalacqua G, Ryan D, Valovirta E, Yorgancioglu A, Aberer W, Agache I, Adachi M, Akdis CA, Akdis M, Annesi-Maesano I, Ansotegui IJ, Anto JM, Arnavielhe S, Arshad H, Baiardini I, Baigenzhin AK, Barbara C, Bateman ED, Beghé $B$, Bel EH, Ben Kheder A, Bennoor KS, Benson $M$, Bewick M, Bieber T, Bindslev-Jensen C, Bjermer L, Blain $\mathrm{H}$, Boner AL, Boulet LP, Bonini M, Bonini S, Bosse I, Bourret $R$, Bousquet PJ, Braido $F$, Briggs $A H$, Brightling $C E$, Brozek J, Buhl R, Burney PG, Bush A, Caballero-Fonseca F, Calderon MA, Camargos PA, Camuzat T, Carlsen KH, Carr W, Cepeda Sarabia AM, Chavannes NH, Chatzi L, Chen YZ, Chiron R, Chkhartishvili E, Chuchalin AG, Ciprandi G, Cirule I, Correia de Sousa J, Cox L, Crooks G, Costa DJ, Custovic A, Dahlen SE, Darsow U, De Carlo G, De Blay F, Dedeu T, Deleanu D, Denburg JA, Devillier $P$, Didier A, Dinh-Xuan AT, Dokic $D$, Douagui $H$, Dray G, Dubakiene R, Durham SR, Dykewicz MS, El-Gamal Y, Emuzyte R, Fink Wagner A, Fletcher $M$, Fiocchi A, Forastiere F, Gamkrelidze A, Gemicioğlu B, Gereda JE, González Diaz S, Gotua M, Grouse L, Guzmán MA, Haahtela T, Hellquist-Dahl B, Heinrich J, Horak F, Hourihane JO, Howarth $P$, Humbert $M$, Hyland ME, Ivancevich JC, Jares EJ, Johnston $\mathrm{SL}$, Joos $\mathrm{G}$, Jonquet $\mathrm{O}$, Jung $\mathrm{KS}$, Just J, Kaidashev I, Kalayci O, Kalyoncu AF, Keil T, Keith PK, Khaltaev N, Klimek L, Koffi N'Goran B, Kolek V, Koppelman GH, Kowalski ML, Kull I, Kuna P, Kvedariene V, Lambrecht B, Lau S, Larenas-Linnemann D, Laune D, Le LT, Lieberman P, Lipworth B, Li J, Louis R, Magard Y, Magnan A, Mahboub B, Majer I, Makela MJ, Manning P, De Manuel Keenoy E, Marshall GD, Masjedi MR, Maurer M, Mavale-Manuel S, Melén E, Melo-Gomes E, Meltzer EO, Merk H, Miculinic N, Mihaltan F, Milenkovic B, Mohammad Y, Molimard M, Momas I, Montilla-Santana A, Morais-Almeida $M$, Mösges R, Namazova-Baranova $L$, Naclerio $R$, Neou $A$, Neffen $H$, Nekam $K$, Niggemann B, Nyembue TD, O'Hehir RE, Ohta K, Okamoto Y, Okubo K, Ouedraogo S, Paggiaro P, Pali-Schöll I, Palmer S, Panzner P, Papi A, Park HS, Pavord I, Pawankar R, Pfaar O, Picard R, Pigearias B, Pin I, Plavec D, Pohl W, Popov TA, Portejoie F, Postma D, Potter P, Price D, Rabe KF, Raciborski F, Radier Pontal F, Repka-Ramirez S, RobaloCordeiro C, Rolland C, Rosado-Pinto J, Reitamo S, Rodenas 
F, Roman Rodriguez M, Romano A, Rosario N, Rosenwasser L, Rottem M, Sanchez-Borges M, Scadding GK, Serrano E, Schmid-Grendelmeier P, Sheikh A, Simons FE, Sisul JC, Skrindo I, Smit HA, Solé D, Sooronbaev T, Spranger O, Stelmach $R$, Strandberg T, Sunyer J, Thiis C, Todo-Bom A, Triggiani M, Valenta R, Valero AL, van Hage M, Vandenplas O, Vezzani G, Vichyanond P, Viegi G, Wagenmann M, Walker S, Wang DY, Wahn U, Williams DM, Wright J, Yawn BP, Yiallouros PK, Yusuf OM, Zar HJ, Zernotti ME, Zhang L, Zhong N, Zidarn M, Mercier J. MACVIA-ARIA Sentinel Network for allergic rhinitis (MASKrhinitis): the new generation guideline implementation. Allergy. 2015;70:1372-92

8. Pizzulli A, Perna S, Florack J, Pizzulli A, Giordani P, Tripodi S, Pelosi S, Matricardi PM. The impact of telemonitoring on adherence to nasal corticosteroid treatment in children with seasonal allergic rhinoconjunctivitis. Clin Exp Allergy. 2014;44:1246-54.

9. Tripodi S, Comberiati P, Di Rienzo Businco A. A web-based tool for improving adherence to sublingual immunotherapy. Pediatr Allergy Immunol. 2014 Oct;25:611-2.

Manuscript received January 27, 2016; accepted for publication February 25, 2016.

Paolo Maria Matricardi Department of Pediatric Pneumology and Immunology Charité Medical University Augustenburger Platz 1 13353 Berlin, Germany E-mail: paolo.matricardi@charite.de

\section{Oral Immunotherapy for Management of Peanut Allergy in Spanish Children}

Vila L, Amado A

Pediatric Allergy Unit, Children's Hospital Teresa Herrera, La Coruña, Spain

J Investig Allergol Clin Immunol 2016; Vol. 26(3): 207-209 doi: $10.18176 /$ jiaci.0061

Key words: Food oral immunotherapy. Oral tolerance induction. Peanut allergy. Desensitization.

Palabras clave: Inmunoterapia oral con alimentos. Inducción de tolerancia oral. Alergia a cacahuete. Desensibilización.

In Spain, nuts and fruits are the main cause of food allergy in children aged $>5$ years [1]. Allergy to peanuts is the most common cause of fatal and near-fatal allergic reactions to foods and seems to be lifelong, since only $20 \%$ of allergic children outgrow it [2].

Oral immunotherapy (OIT) is a new approach in the management of food-allergic patients. It is based on the administration of small amounts of allergen that are gradually increased with the aim of inducing desensitization as a first step toward achieving tolerance [3].

Table. Protocol for Oral Immunotherapy With Peanut

Induction phase: doses were administered at the hospital. The starting dose was adjusted for each patient according to the dose that elicited allergic manifestations during the open food challenge.

\begin{tabular}{cc}
\hline Week & Roasted Peanuts, g \\
\hline $1^{\mathrm{a}}$ & $0.025-0.05-0.1$ \\
2 & 0.2 \\
3 & 0.4 \\
4 & 1 \\
5 & 1.5 \\
6 & 3 \\
7 & 5 \\
\hline
\end{tabular}

aThe starting dose was established by open food challenge and set at the dose preceding the dose that elicited symptoms. Initially, dry roasted peanuts were ground and mixed with yogurt. When $1 \mathrm{~g}$ was reached, peanuts were administered as is. Oral disodium cromoglycate (100 mg every 8 hours) was administered during this phase.

Maintenance phase: doses were administered at home

$5 \mathrm{~g}$ of roasted peanut daily for 3 months.

5 g 2-3 times a week afterwards. 
Most studies on OIT with peanut have been performed in the United Kingdom and the United States of America, where peanut allergy is considered a matter of public health. Although peanut allergy is less prevalent in Spain than in the United States of America, patients are mostly sensitized to the lipid transfer protein (LTP) Ara h 9, which is associated with severe systemic reactions [4].

Using OIT we aimed to reach an amount of peanut that was sufficient to avoid severe adverse reactions in case of accidental exposure. Our OIT protocol is summarized in the Table. Informed consent was obtained from each family before the protocol was started.

The first patient was a 5-year-old girl with atopic dermatitis (AD) and rhinitis who was sensitized to dust mites. At 4 years of age she developed generalized urticaria, vomiting, and abdominal pain after ingestion of roasted peanuts. The result of a skin prick test (SPT) with peanut extract (ALK-Abelló) was positive $(12 \mathrm{~mm})$. Total serum $\mathrm{IgE}$ was $88.5 \mathrm{kU} / \mathrm{L}$ and peanut specific IgE was $14.3 \mathrm{kU}_{\mathrm{A}} / \mathrm{L}$ (Thermo Fisher Scientific). We started OIT after establishing an initial dose of $0.025 \mathrm{~g}$ by open food challenge (OFC). The induction phase took 9 weeks, during which the patient presented vomiting and oral itching on 2 occasions.

She has been on maintenance treatment for 6 months and has not reported allergic reactions to peanut.

The second patient was a 5-year-old boy with $\mathrm{AD}$, rhinitis, and bronchial asthma who was sensitized to dust mites. At 4 years of age, he developed contact urticaria after touching roasted peanuts. SPT with 1 peanut (ALK-Abelló) was positive $(11 \mathrm{~mm})$. During OFC with roasted peanuts he developed oral itching and perioral urticaria after ingestion of $0.1 \mathrm{~g}$. OIT was started with an initial dose of $0.05 \mathrm{~g}$. The induction phase took 10 weeks, and during this time, he presented a rash on his chest on 1 occasion.

At the beginning of the maintenance phase, the patient developed abdominal pain after inadvertently ingesting $10 \mathrm{~g}$ of peanut. From that moment on, he refused to eat peanuts and therefore did not keep up with his recommended daily intake, eating peanuts only now and then. Two weeks later, during vigorous play after eating peanuts, he developed urticaria on his face and chest that resolved with oral antihistamines and corticosteroids. He subsequently dropped out of the protocol, although he tolerates foods with trace amount of peanuts.

The third patient was a 12 -year-old boy with $\mathrm{AD}$, rhinitis, and bronchial asthma who was allergic to kiwi and sensitized to dust mites. He had previously undergone desensitization to egg. At 18 months of age, he developed facial urticaria and angioedema after placing a single peanut in his mouth. The result of SPT to peanut (ALK-Abelló) was positive $(8 \mathrm{~mm})$. Total $\mathrm{IgE}$ was $175 \mathrm{kU} / \mathrm{L}$ and peanut specific IgE was $1.53 \mathrm{kU}_{\mathrm{A}} / \mathrm{L}$ (Thermo Fisher Scientific). At 7 years of age, he developed generalized urticaria and difficulty breathing after eating potato chips fried in peanut oil. Two years later, he developed urticaria on his face and chest after ingesting 0.5 $\mathrm{g}$ of peanut during an OFC. OIT was started with an initial dose of $0.025 \mathrm{~g}$. The induction phase took 10 weeks, during which time he developed oral itching on 2 occasions. He has been on maintenance treatment for the last 3 years and has not reported adverse reactions.
The fourth patient was a 13 -year-old girl with $\mathrm{AD}$, rhinitis, and bronchial asthma who was sensitized to dust mites and Alternaria alternata. When she was 3 years old, she developed facial urticaria and oral pruritus after ingestion of 1 peanut. The result of SPT was positive $(6 \mathrm{~mm})$ for peanut (ALK-Abelló). Total IgE was $534 \mathrm{kU} / \mathrm{L}$ and peanut specific $\operatorname{IgE}$ was $2 \mathrm{kU} / \mathrm{L}$ (Thermo Fisher Scientific). OFC performed at age 11 years confirmed persistence of peanut allergy. The patient started OIT at an initial dose of $0.1 \mathrm{~g}$. The induction phase took 9 weeks, during which time she complained of mild oral itching on 5 occasions that resolved spontaneously.

She has not reported adverse reactions during the last 2 years of the maintenance phase.

Most studies on OIT to peanut show that a high percentage of patients achieve complete desensitization [5-7]. Moreover, reports of immunological changes [5-7] suggest that OIT modulates the immune response towards tolerance in peanutallergic patients. Recently, Syed et al [8] demonstrated epigenetic changes in patients' immune tolerance to peanut after OIT, namely, increased methylation of FOXP3 CpG sites in antigen-induced regulatory $\mathrm{T}$ cells.

To date, only 1 patient has undergone OIT for allergy to peanut. The patient was a 6-year-old child who tolerated 5.5 $\mathrm{g}$ of peanuts after a 138-day induction phase [9].

Of the 4 patients we present here, 3 achieved the target dose of $5 \mathrm{~g}$ of peanut after a 9 to 10 -week induction phase and can now tolerate peanut.

Adverse reactions during OIT to peanut are mild and usually affect the skin, gastrointestinal tract, and upper respiratory tract $[5-7,9]$. The frequency of adverse reactions during the induction phase ranges from $1.2 \%$ [5] and $2.6 \%$ [6] to $46 \%$ [7]. These differences are probably related to the type of protocol applied and the target dose of peanut to be reached. We found that $18 \%$ of adverse reactions were related to the doses administered during the induction phase. Oral itching was the most frequent adverse reaction reported. Two mild reactions were observed in only 1 patient during the maintenance phase.

Patients on maintenance treatment and their families reported an improvement in quality of life in terms of allergen avoidance, risk of accidental exposure, and limitations at social occasions such as birthday parties. This issue has been assessed by Anagnostou et al [10] and constitutes another factor that tips the scale in favor of OIT.

Based on our limited experience and that of other authors, OIT to treat peanut allergy seems to be a safe procedure that elicits mild adverse reactions and improves quality of life for both patients and their families.

\section{Acknowledgments}

We would like to thank our nurse, Ofelia Alba Lago, for her help with the follow-up of the patients.

\section{Funding}

The authors declare that no funding was received for the present study.

\section{Conflicts of Interest}

The authors declare that they have no conflicts of interest. 


\section{References}

1. Garde J, Ibañez M. Alergia en menores de 14 años en Alergológica 2005, factores epidemiológicos, clínicos y socioeconómicos de las enfermedades alérgicas en España en 2005. SEAIC, Shering-Plough, Luzán. SA Ediciones, Madrid.

2. Peters RL, Allen KJ, Dharmage SC, Koplin JJ, Dang T, Tilbrook KP, Lowe A, Tang ML, Gurrin LC; HealthNuts Study. Natural history of peanut allergy and predictors of resolution in the first 4 years of life: A population-based assessment. J Allergy Clin Immunol. 2015 May; 135(5):1257-66.

3. Ibañez MD, Escudero C, Sánchez-García S, Rodríguez del Río P. Comprehensive review of current knowledge on egg oral immunotherapy. J Investig Allergol Clin Immunol. 2015;25(5):316-28.

4. Vereda A, van Hage M, Ahlstedt S, Ibañez MD, Cuesta-Herranz J, van Odijk J, Wickman M, Sampson HA. Peanut allergy: clinical and immunologic differences among patients from 3 different geographic regions. JACI. 2011;127:603-7.

5. Varshney P, Jones $S$, Scurlock $A$, Perry $T$, Kemper $A$, Steele $P_{1}$ Hiegel A, Kamilaris J, Carlisle S, Yue X, Kulis M, Pons L, Vickery B, Burks W. A randomized controlled study of peanut oral immunotherapy: Clinical desensitization and modulation of the allergic response. J Allergy Clin Immunol. 2011;127:654-60.

6. Blumchen K, Ulbricht H, Staden U, Dobberstein K, Beschorner J, Camargo Lopes de Oliveira L, Shreffler W, Sampson HA, Niggemann B, Wahn U, Beyer K. Oral immunotherapy in children with peanut anaphylaxis. J Allergy Clin Immunol. 2010;126:83-91.

7. Jones S, Pons L, Roberts J, Scurlock A, Perry TT, Kulis $M$, Shreffler WG, Steele P, Henry KA, Adair M, Francis JM, Durham S, Vickery BP, Zhong X, Burks AW. Clinical efficacy and immune regulation with peanut oral immunotherapy. J Allergy Clin Immunol. 2009;124:292-300.

8. Syed A, García M, Lyu S, Bucayu R, Kohli A, Ishida S, Berglund J, Tsai M, Maecker H, O'Riordan G, Galli S, Nadeau K. Peanut oral immunotherapy results in increased antigen-induced regulatory T-cell function and hypomethylation of forkhead box protein 3 (FOXP3). J Allergy Clin Immunol. 2014;133:500-10.

9. Ojeda P, Ojeda I, Pineda F, Alfaya T, Ojeda JA. Induction of oral tolerance to peanut: a successful home-based protocol. J Investig Allergol Clin Immunol. 2010; Vol. 20(6):524-8.

10. Anagnostou K, Islam S, King Y, Foley L, Pasea L, Bond S, Palmer C, Deighton J, Ewan P, Clark A. Assessing the efficacy of oral immunotherapy for the desensitisation of peanut allergy in children (STOP II): a phase 2 randomised controlled trial. Lancet. 2014;383(9925):1297-1304.

- Manuscript received January 13, 2016; accepted for publication March 8, 2016.

Leticia Vila Sexto

Pediatric Allergy Unit Hospital Materno-Infantil Teresa Herrera

C/ As Xubias, s/n

15006, La Coruña

E-mail: leticia.vila.sexto@sergas.es
Asthma and Allergic Diseases in a Selected Group of Patients With Common Variable Immunodeficiency

Yazdani $\mathrm{R}^{1,2}$, Heydari $\mathrm{A}^{2}$, Azizi $\mathrm{G}^{3,2}$, Abolhassani $\mathrm{H}^{2,4}$, Aghamohammadi $\mathrm{A}^{2}$

${ }^{1}$ Department of Immunology, School of Medicine, Isfahan University of Medical Sciences, Isfahan, Iran

${ }^{2}$ Research Center for Immunodeficiencies, Pediatrics Center of Excellence, Children's Medical Center, Tehran University of Medical Sciences, Tehran, Iran

${ }^{3}$ Imam Hassan Mojtaba Hospital, Alborz University of Medical Sciences, Karaj, Iran; Research Center for Immunodeficiencies, Tehran University of Medical Sciences, Tehran, Iran

${ }^{4}$ Division of Clinical Immunology, Department of Laboratory Medicine, Karolinska Institute at Karolinska University Hospital Huddinge, Stockholm, Sweden

J Investig Allergol Clin Immunol 2016; Vol. 26(3): 209-211 doi: $10.18176 /$ jiaci.0062

Key words: Common variable immunodeficiency. Asthma and allergic diseases. Clinical manifestations. Immunological findings.

Palabras clave: Inmunodeficiencia común variable. Asma y enfermedades alérgicas. Manifestaciones clínicas. Hallazgos inmunológicos.

Common variable immunodeficiency (CVID) is the most common symptomatic primary immune deficiency. It is characterized by decreased serum Ig concentrations of at least 2 isotypes in patients older than 4 years with confirmed specific antibody deficiency against protein and polysaccharide antigens [1]. Although several genetic defects have been identified in the pathogenesis of CVID [2], the basic molecular defect remains unknown. The main clinical manifestations in CVID patients are recurrent infections of the respiratory and gastrointestinal tracts, autoimmune disorders, enteropathy, and lymphoproliferative diseases [1]. Furthermore, mucosal immunodeficiency in patients with CVID could predispose to development of allergic reactions to aeroallergens, inflammation, and bronchial hyperresponsiveness, as reported in IgA deficiency [3]. However, little evidence is available on the prevalence of asthma and allergic diseases in patients with CVID. The purpose of the present study was to report the prevalence of asthma and allergic disease in patients with CVID and to evaluate the association between asthma and allergic diseases and clinical and immunological data from patients attended at our center.

We analyzed data on asthma and allergic diseases, clinical manifestations, and immunological findings from 187 patients (112 males and 75 females) referred to the Children's Medical Center, Pediatrics Center of Excellence, which is affiliated with the Tehran University of Medical Sciences, Tehran, Iran. Food allergy was defined as a convincing history of food allergy and/or self-reporting of a physician-diagnosed food allergy. The inhalant allergens were trees (elm, maple, oak), grasses (Bermuda grass, Johnson grass, June grass 
[Kentucky bluegrass]), weeds (common ragweed, cocklebur, rough pigweed), molds, and miscellaneous allergens (mite, dog dander, cat dander, cockroach). CVID patients were divided into 2 groups: CVID patients with asthma and allergic diseases (Group A) and CVID patients without asthma and allergic diseases (Group B).

Clinical and immunological data are presented in the Table. Of the 187 patients, $22(11.7 \%)$ had asthma and allergic diseases, and $7(3.7 \%)$ presented more than 1 allergic manifestation. Only 5 individuals had been referred with allergic complications as their first manifestation before diagnosis of CVID. Twenty patients $(10.6 \%)$ had at least 1 firstdegree relative with allergic manifestations. The prevalence of asthma and allergic disorders in CVID patients are presented in the Table.

The mean (SD) serum level of IgM at diagnosis was significantly lower in Group A than in Group B (29.0 [21.9] vs $44.2[6.2] \mathrm{mg} / \mathrm{dL} ; P=.03)$, whereas the level of $\mathrm{IgE}$ was significantly higher (median, $41.62 \mathrm{IU} / \mathrm{mL}$ vs $30.18 \mathrm{IU} / \mathrm{mL}$; $P=.04$ ). Significant differences between Group A and Group B were observed for anti-IgA antibody level (5.06 [3.3] vs 1.6 [1.0] IU/mL; $P=.02)$ and $\operatorname{IgE}$ after stimulation (6.13 [5.5] vs 3.17 [2.8] IU/mL; $\mathrm{P}=.01)$. Furthermore, a comparison of the clinical complications between the 2 groups revealed significantly more frequent upper respiratory tract infections (8.3 [7.4] vs 5.8 [4.7]; $P=.001)$ and bronchiectasis $(50 \%$ vs $26 \% ; P=.003)$ in Group A than in Group B.

The prevalence of asthma and allergic disorders in patients with CVID reported elsewhere [4-6] was higher than that found in our study (12\%). This discrepancy could be due to the difference in sample size, underlying genetic defects, and ethnic composition. Moreover, as our patients were predominantly Caucasian, our findings cannot be applied to other ethnic groups. Asthma and other atopic diseases in patients with CVID can be caused by immune dysregulation, association with some specific major histocompatibility complex haplotypes, reduced IgA response to luminal allergen challenge, increased levels of serum IgE due to a compensatory mechanism for reducing other Ig classes, and prolonged respiratory infections. Consistent with other studies, we found that few patients had allergic rhinitis $(1 \%)[4,5]$. However, Eguíluz-Gracia et al [6] and Agondi et al [7] found a greater prevalence of allergic rhinitis (35.5\% and $43 \%$, respectively). Food and drug allergies were also less frequent than reported elsewhere $[4,6,8]$, whereas urticaria was more frequent $[6,9]$. Atopic dermatitis affected the same percentage of patients in

Table. Clinical and Immunological Data for 187 Patients With CVID

\begin{tabular}{|c|c|c|c|c|}
\hline Parameters & Total $(\mathrm{N}=187)$ & Group A $(n=22)$ & Group B $(n=165)$ & $P$ Value $^{\mathrm{a}}$ \\
\hline Asthma, \% & $9(4.8)$ & $9(40.9)$ & - & - \\
\hline Atopic dermatitis, $\%$ & $6(3.2)$ & $6(27.2)$ & - & - \\
\hline Allergic eczema, $\%$ & $4(2.1)$ & $4(18.1)$ & - & - \\
\hline Food allergy, \% & $5(2.6)$ & $\begin{array}{c}2 \text { patients with allergy to pistachios } \\
\text { and } 3 \text { patients with allergy } \\
\text { to eggplant }(22.7)\end{array}$ & - & - \\
\hline Urticaria, \% & $4(2.1)$ & $\begin{array}{l}4 \text { chronic, } 1 \text { induced by } \\
\text { exposure to sunlight (18.1) }\end{array}$ & - & - \\
\hline Allergic rhinitis, $\%$ & $2(1.0)$ & $2(9.0)$ & - & - \\
\hline Allergic conjunctivitis, $\%$ & $2(1.0)$ & $2(9.0)$ & - & - \\
\hline Drug allergy, $\%$ & $2(1.0)$ & $2(9.0)$ & - & - \\
\hline Anaphylactic reactions to IVIG, \% & $1(0.5)$ & $1(4.5)$ & - & - \\
\hline Dust allergy, \% & $1(0.5)$ & $1(4.5)$ & - & - \\
\hline $\begin{array}{l}\text { Mean (SD) upper respiratory } \\
\text { tract infections per person }\end{array}$ & $6.2(3.7)$ & $8.3(7.4)$ & $5.8(4.7)$ & .001 \\
\hline $\begin{array}{l}\text { Mean (SD) lower respiratory } \\
\text { tract infections per person }\end{array}$ & $3.2(2.4)$ & $3.7(3.5)$ & $2.7(1.3)$ & .43 \\
\hline Bronchiectasis, $\%$ & $54(31)$ & $11(50.0)$ & $43(26.0)$ & .03 \\
\hline Mean (SD) IgG, mg/dL & $277.1(214.5)$ & $284.3(197.6)$ & $278.0(217.0)$ & .61 \\
\hline Mean (SD) IgM, mg/dL & $42.7(5.9)$ & $29.0(21.9)$ & $44.2(6.2)$ & .03 \\
\hline Mean (SD) IgA, mg/dL & $26.3(4.2)$ & $20.3(3.5)$ & $27.5(4.3)$ & .65 \\
\hline Mean (SD) IgE, IU/mL & $32.1(6.1)$ & $41.62(6.3)$ & $30.18(4.6)$ & .04 \\
\hline Mean (SD) anti-IgA level, IU/mL & $2.4(1.3)$ & $5.06(3.3)$ & $1.6(1.0)$ & .02 \\
\hline Mean (SD) poststimulation IgE, IU/mL & $4.2(1.0)$ & $6.13(5.5)$ & $3.17(2.8)$ & .01 \\
\hline
\end{tabular}

Abbreviations: CVID, common variable immunodeficiency; IVIG, intravenous immunoglobulin.

${ }^{\text {a }} P$ value significant at $<.05$. 
our study (3.2\%) as reported by Eguíluz-Gracia et al, although our finding was higher than that reported by Ramírez-Vargas et al $(0.4 \%)$ [4] and lower than that reported by Tuano et al $(4.4 \%)[8]$.

A significantly higher IgE titer and significantly lower IgM titer were found in patients with asthma and allergic diseases than in the other patients. Increased IgE in Group A suggests the possibility of atopic diseases resulting from skewed Ig class switching to IgE, as confirmed by the high levels of IgE after stimulation. CVID patients with decreased IgM have been shown to be more susceptible to developing bronchiectasis [10]. We consistently showed that upper respiratory infections and bronchiectasis were significantly more common in Group A than in Group B. Moreover, the significantly higher anti-IgA antibody level in Group A could be associated with anaphylactic reaction to intravenous immunoglobulin.

Although infectious diseases are the most common clinical manifestation in patients with CVID, the result of the present study showed that asthma and allergic diseases were also observed in a significant proportion of patients. The development of asthma and allergic diseases in patients with CVID could be associated with immune dysregulation, skewing of the immune system towards a type 2 helper T-cell phenotype, and prolonged respiratory infections.

Our findings show that asthma and allergic diseases are associated with CVID in some cases. Diagnosing asthma and allergic diseases could improve management and, eventually, the quality of life of patients with CVID. Therefore, immunologists and physicians should be aware of these conditions. Moreover, we suggest that this study could be complemented with patients from other countries. Indeed, a prospective study with a larger number of patients would fully elucidate the association between asthma and allergic diseases and CVID.

\section{Funding}

The authors declare that no funding was received for the present study.

\section{Conflicts of Interest}

The authors declare that they have no conflicts of interest.

\section{References}

1. Aghamohammadi $A$, Abolhassani $H$, Moazzami K, Parvaneh $\mathrm{N}$, Rezaei N. Correlation Between Common Variable Immunodeficiency Clinical Phenotypes and Parental Consanguinity in Children and Adults. J Investig Allergol Clin Immunol. 2010;20:372.

2. Yazdani $R$, Hakemi MG, Sherkat $R$, Homayouni $V$, Farahani $R$. Genetic defects and the role of helper T-cells in the pathogenesis of common variable immunodeficiency. Adv Biomed Res. 2014;3:2.

3. Yazdani R, Latif A, Tabassomi F, Abolhassani H, Azizi G, Rezaei $\mathrm{N}$, Aghamohammadi A. Clinical phenotype classification for selective immunoglobulin A deficiency. Expert Rev Clin Immunol. 2015;11:1245-54.
4. Ramírez-Vargas N, Arablin-Oropeza SE, Mojica-Martínez D, Yamazaki-Nakashimada MA, de la Luz García-Cruz M, Terán-Juárez LM, Cortés-Grimaldo RM, Torres-Lozano C, Madrigal-Beas I, Ortega-Cisneros M, Vargas-Camaño ME, Staines-Boone T, Pietropaolo-Cienfuegos D, BerrónRuiz L, Espinosa-Rosales F, Guevara-Cruz M, BlancasGalicia L. Clinical and immunological features of common variable immunodeficiency in Mexican patients. Allergol Immunopathol. 2014;42:235-40.

5. Agondi R, Barros M, Rizzo L, Kalil J, Giavina-Bianchi P. Allergic asthma in patients with common variable immunodeficiency. Allergy. 2010;65:510-5.

6. Eguíluz-Gracia I, Fernández-Cruz E, Carbone J. High prevalence of allergy-like respiratory diseases in common variable immunodeficiency. J Investig Allergol Clin Immunol. 2013;23:209-11.

7. Agondi RC, Barros MT, Kokron CM, Cohon A, Oliveira AK, Kalil J, Giavina-Bianchi P. Can patients with common variable immunodeficiency have allergic rhinitis? Am J Rhinol Allergy. 2013;27:79-83.

8. Tuano KS, Orange JS, Sullivan K, Cunningham-Rundles C, Bonilla FA, Davis CM. Food allergy in patients with primary immunodeficiency diseases: Prevalence within the US Immunodeficiency Network (USIDNET). J Allergy Clin Immunol. 2015;135:273.

9. Altschul A, Cunningham-Rundles C. Chronic urticaria and angioedema as the first presentations of common variable immunodeficiency. J Allergy Clin Immunol. 2002;110:664-5.

10. Carsetti R, Rosado MM, Donnanno S, Guazzi V, Soresina A Meini A, Plebani A, Aiuti F, Quinti I. The loss of IgM memory $B$ cells correlates with clinical disease in common variable immunodeficiency. J Allergy Clin Immunol. 2005;115:412-7.

Manuscript received February 9, 2016; accepted for publication March 8, 2016.

Asghar Aghamohammadi Children's Medical Center Hospital, 62 Qarib St., Keshavarz Blvd. Tehran 14194, Iran E-mail: aghamohammadi@sina.tums.ac.ir 